\title{
Hawksworthiomyces gen. nov. (Ophiostomatales), illustrates the urgency for a decision on how to name novel taxa known only from environmental nucleic acid sequences (ENAS)
}

\author{
Z. Wilhelm DE BEER ${ }^{a, *}$, Seonju MARINCOWITZ ${ }^{a}$, Tuan A. DUONG ${ }^{b}$, \\ Jae-Jin KIM $^{\mathrm{c}}$, Andre RODRIGUES ${ }^{d}$, Michael J. WINGFIELD ${ }^{a}$ \\ ${ }^{a}$ Department of Microbiology and Plant Pathology, University of Pretoria, Pretoria 0002, South Africa \\ ${ }^{b}$ Department of Genetics, Forestry and Agricultural Research Institute (FABI), University of Pretoria, Pretoria 0002, \\ South Africa \\ ${ }^{\mathrm{C}}$ Division of Environmental Science and Ecological Engineering, Korea University, 5-1 Anam-dong, Seongbuk-gu, \\ Seoul 136-701, South Korea \\ ${ }^{\mathrm{d} D e p a r t m e n t}$ of Biochemistry and Microbiology, UNESP - São Paulo State University, 13506-900, Rio Claro, SP, \\ Brazil
}

\section{A R T I C L E I N F O}

\section{Article history:}

Received 14 February 2016

Received in revised form

2 July 2016

Accepted 12 July 2016

Available online 29 July 2016

Corresponding Editor:

Geoffrey Gadd

Keywords:

Melbourne Code

Nomenclature

Operational taxonomic units

Ophiostoma

Sporothrix

\begin{abstract}
A B S T R A C T
There have been many recent studies using environmental nucleic acid sequences (ENAS) to assess fungal diversity. As a result, more than a third of all fungal sequences in GenBank are of environmental origin. But inconsistent annotation of the thousands of undescribed taxa represented by these sequences limits access to these data. Consequently, these ENAS and the taxa they represent are rarely considered in other studies, and especially not in taxonomic treatments. This problem is confounded by the fact that the current version of the International Code of Nomenclature for Algae, Fungi, and Plants (Melbourne Code) prohibits the description of novel taxa known only from ENAS. There have been suggestions to emend the Code to allow a systematic nomenclatural treatment of these currently 'orphan' taxa but this has yet to occur. In this study, we considered the feasibility of using sequences from environmental studies to resolve the generic status of Sporothrix lignivora. This species forms a single lineage distinct from Sporothrix and other genera in the Ophiostomatales. BLAST searches in GenBank using LSU and ITS sequences of S. lignivora corresponded with several sequences from environmental studies. This also led to the discovery of isolates collected in diversity studies based on culturable fungi, with high similarity to S. lignivora. Phylogenetic analyses including taxa representing all major genera and lineages in the Ophiostomatales revealed a distinct, well-supported lineage that included S. lignivora and the ENAS. This confirmed the presence of a new genus in the Ophiostomatales described here as Hawksworthiomyces gen. nov., with S. lignivora as type species. Whereas only one described species was known in the so-called S. lignivora complex, our analyses revealed nine additional lineages in what is now Hawksworthiomyces. For three of these lineages, we were able to obtain isolates and these are described as Hawksworthiomyces taylorii sp. nov., Hawksworthiomyces crousii sp. nov., and Hawksworthiomyces hibbettii
\end{abstract}

\footnotetext{
* Corresponding author. Tel.: +27 12 4203938; fax: +27 124203960.

E-mail address: wilhelm.debeer@fabi.up.ac.za (Z. Wilhelm de Beer).
}

http://dx.doi.org/10.1016/j.funbio.2016.07.004

1878-6146/@ 2016 British Mycological Society. Published by Elsevier Ltd. All rights reserved. 
sp. nov. Five of the lineages each included one or more sequences from single studies, and thus remain unnamed. The remaining lineage included two sequences from separate studies of fungi inhabiting conifer wood. One of these sequences was an uncultured fungus clone from a spruce log in Sweden. The other sequence was for an isolate from a western red cedar fencepole in British Columbia, Canada, that was subsequently lost. These two ITS sequences differ in only two nucleotide positions. We are confident that they represent the same taxon and meet the criteria for an ENAS species, for which we provide the name, Hawksworthiomyces sequentia sp. nov. ENAS, and designate a DNA sequence as type in the absence of a type specimen. This case study makes it clear that environmental sequences and those from lost isolates can be extremely valuable in phylogeny-based taxonomic studies. It emphasises the fact that the Code should be emended to enable the naming of such taxa in a manner that will facilitate their incorporation in other studies.

() 2016 British Mycological Society. Published by Elsevier Ltd. All rights reserved.

\section{Taxonomic novelties}

Hawksworthiomyces Z.W. de Beer, Marinc., M.J. Wingf. gen. nov.; Hawksworthiomyces lignivorus (De Meyer, Z.W. de Beer, M.J. Wingf.) Z.W. de Beer, Marinc., M.J. Wingf. comb. nov.; Hawksworthiomyces taylorii Z.W. de Beer, Marinc., M.J. Wingf. sp. nov.; Hawksworthiomyces crousii Z.W. de Beer, Marinc., M.J. Wingf. sp. nov.; Hawksworthiomyces hibbettii Z.W. de Beer, Marinc., M.J. Wingf. sp. nov.; Hawksworthiomyces sequentia Z.W. de Beer, T.A. Duong, M.J. Wingf. sp. nov. ENAS.

\section{Introduction}

"... If one does not name the organisms, one does not know of them. Such organisms would just be ... spots in a jungle or, as is the case of millions of organisms even today, they would not exist for us at all ...”--- Jouni Issakainen (Issakainen 1999)

The impact of DNA sequencing on fungal taxonomy and nomenclature during the past 25 years has been dramatic (Taylor 2011; Hibbett \& Taylor 2013). In 1992, Berbee \& Taylor (1992) showed that it is possible to link sexual and asexual fungi in molecular phylogenies based on DNA sequences. Within a decade, most major taxonomic treatments included phylogenies based on sequences, and in 2011 the practice of dual nomenclature was abandoned and the necessary changes were made to the Code to enforce 'one fungus one name' principles (Hawksworth et al. 2011; McNeill et al. 2012).

Not only were genera redefined, but DNA sequences have rapidly led to the formulation of new species concepts in fungi. Of these, Genealogical Concordance Phylogenetic Species Recognition (GCPSR) based on unlinked sets of characters (Taylor et al. 2000, 2006a,b), has become the standard for all the major contemporary taxonomic works. In phylogenetic studies applying the GCPSR, the name assigned to a lineage representing a species, is typically determined by DNA sequences of the type specimen or ex-type isolate of that species. To facilitate DNA-based species recognition, the ITS region (ribosomal internal transcribed spacer regions 1 and 2, including the $5.8 \mathrm{~S}$ subunit) was accepted as universal barcode for fungi with the intention that every fungal species would be represented by a sequence in online databases (Schoch et al. 2012). Following the selection of the barcode, GenBank has established the curated, RefSeq Targeted Loci (RTL) database, where public sequence accessions were confirmed to be linked to valid species names and correctly annotated type specimens (Schoch et al. 2014). ITS has also become the gene region used most often in DNA-based surveys considering fungal diversity in different environments (Kõljalg et al. 2013). Since it is understood that the ITS does not always distinguish between closely related species, a more sensitive barcoding region (translation elongation factor 1- $\alpha$ ) was recently recommended to be used in addition to ITS for fungal barcoding (Stielow et al. 2015).

The estimated number of fungal species on earth remains a matter of considerable debate (Hawksworth 2001; O'Brien et al. 2005; Mueller \& Schmit 2007; Blackwell 2011). But it is clear that DNA sequences have contributed substantially to the rate of taxon discovery and that millions of species remain undescribed. A small part of this increase in numbers of newly discovered taxa is due to an improved ability to distinguish between cryptic species, but it is fungal molecular ecologists that are now at the forefront of species discovery (Hibbett et al. 2009, 2011; Hibbett \& Glotzer 2011). By 2011 more than a third of all fungal sequences in GenBank were of environmental origin (e.g. soil, wood, leaf litter, etc.). This is in contrast to sequences for the remaining taxa that were primarily from specimens and mostly living cultures (Hibbett et al. 2011). Yet, the number of 'species' added annually to GenBank had already 'tipped' by 2009 in favour of environmental nucleic acid sequences (ENAS), as opposed to specimen-based sequences (Hibbett et al. 2011; Hibbett \& Glotzer 2011; Taylor 2011).

In most environmental studies, sequences are grouped based on similarity into molecular operational taxonomic units (MOTUs), species hypotheses (SHs) or virtual taxa (VT) (Ryberg et al. 2008; Kõljalg et al. 2013; Öpik et al. 2014; Ryberg 2015). Different studies have applied different criteria in designating these 'taxa', and the naming or coding of MOTUs is generally applied informally and this varies from one study to another (Taylor \& Hibbett 2013). These practices cause major confusion because there is no centralized database compiling all these names in a systematic manner. This makes the 
comparison of MOTUs between different investigations, and the inclusion of ENAS fungi in taxonomic studies, difficult. It also results in a disconnect between molecular ecologists and taxonomists (Hibbett et al. 2011; Hibbett 2016).

Some suggestions have been made to systematically label MOTUs using numbering systems (Abarenkov et al. 2010; Kõljalg et al. 2013; Menkis et al. 2014). Hibbett et al. (2009, 2011) and Taylor \& Hibbett (2013) argued that although such resources have merit because they facilitate discussion among experts, the MOTUs they represent are not translated into Latin binomials. Consequently, they are not integrated into species-based biodiversity databases such as MycoBank, Index Fungorum, the Catalogue of Life, etc. The unfortunate outcome is that this rich source of fungal diversity data is seldom considered in contemporary taxonomic treatments. Thus, these taxa remain largely unknown to the broader community of evolutionary and conservation biologists, pathologists concerned with human, animal and plant health, and other practitioners concerned with fungi.

The rapidly increasing numbers of unnamed ENAS fungi threatens to submerge fungal nomenclature in chaos. The mycological community must take timely action to prevent this from happening by making provision for these in the Code. To date, the Code has promoted and guided the consistent application of taxon names based on and requiring specimens. However, it does not allow the naming of taxa known only from sequences. Hibbett et al. (2011) suggested a small set of changes to the Code that will allow these ENAS fungi to be named where a set number of criteria can be met. These suggestions were also incorporated in the Amsterdam Declaration (Hawksworth et al. 2011). And although the majority of other suggested changes in that document were incorporated in the Melbourne Code, the suggestion of how to name ENAS fungi was not included. Additional discussions and a special session on the topic of naming ENAS fungi followed at the 10th International Mycological Congress (IMC10) in Bangkok. The naming of environmental sequences was recognized as a problem for which a solution was required (Redhead et al. 2014). But due to limited time and other priorities during the nomenclature sessions, no resolution was made on how to proceed. A proposal that, subject to minimum standards, the naming of fungi known only as environmental sequences (i.e. with no specimens or cultures) should be permitted by the Code, received a disappointing $44 \%$ of votes in favour (Redhead et al. 2014).

Protagonists of Sequence-Based Classification (SBC) held a workshop linked to the Mycological Society of America (MSA) Meeting in 2014 to address the challenges and best practices for SBC and Sequence-Based Identification (SBI). Among several guidelines for merging SBC and SBI, the group once again called for a modification to the Code allowing for purely sequence-based taxon description (Herr et al. 2015).

Since the first DNA sequences for the Ophiostomatales were published by Berbee \& Taylor (1992), the taxonomy and nomenclature of this group of fungi was driven by all the above-mentioned impacts of sequencing. These impacts, from the sub-species to ordinal ranks, were reviewed by De Beer \& Wingfield (2013) who also constructed the most comprehensive phylogenies of the order to date. They were able to redefine some genera and they addressed several one fungus one name issues pertaining to the order (De Beer \& Wingfield 2013; De Beer et al. 2013). One of the species that was not resolved in their phylogenies, was Sporothrix lignivora. This species grouped as a singleton distinct from and basal to all other species and known genera in the Ophiostomatales (De Beer \& Wingfield 2013). The authors were, however, reluctant to erect a monotypic genus for $\mathrm{S}$. lignivora because sequences for only five isolates of the species were available.

In the preparation for their recent revision of the genus Sporothrix, De Beer et al. (2016) needed to reconsider the placement of S. lignivora. After sequencing additional gene regions, the authors confirmed that this species does not form part of Sporothrix. The results of a BLAST search in GenBank using the ex-type isolate of the species produced a list of interesting hits. Apart from a BLAST hit against itself and two other S. lignivora isolates from the original study (De Meyer et al. 2008), the list included only unidentified or preliminary identified sequences obtained from DNA-based environmental studies or diversity studies based on culturable fungi labelled e.g. as 'Sporothrix sp.', 'Uncultured root-associated fungus clone' or 'Ascomycota sp.' In the present study, we investigated the feasibility of using these environmental sequences from GenBank to resolve the generic status of S. lignivora. Hibbett et al. (2009) suggested that the traditional relationship between taxonomy and ecology should be inverted, and they requested taxonomists to become consumers of the products of ecological studies in their quest to document the global diversity of fungi. By including these unnamed environmental sequences from our BLAST results in our data sets from specimen-based sequences, we have met the challenge of Hibbett et al. (2009), with some intriguing and challenging outcomes.

\section{Materials \& methods}

\section{GenBank sequences and isolates}

BLAST searches were done using the ITS and LSU sequences of the ex-type isolate of Sporothrix lignivora (Table 1) in both NCBI GenBank (Zhang et al. 2000) and the UNITE database (Kõljalg et al. 2013). Sequences and metadata of the BLAST hits were downloaded and in cases where sequences were obtained from culture-based studies, the authors were contacted requesting the relevant isolates. Two authors did not respond, but in three cases the response was that isolates were dead, contaminated or that they had simply not been maintained. Despite these challenges, we received three isolates (Table 1), one each from the studies of Rodrigues et al. (2011), Kim et al. (2011), and Shresta et al. (2011). Unfortunately the isolate from the latter study (Mbale 50-11) proved to be a Cladosporium sp. that did not represent the original taxon, and was thus excluded from further study. One isolate (CMW 20741) obtained during the same survey from which S. lignivora was described (De Meyer et al. 2008), but omitted from that study, was also included.

Isolates are preserved in the culture collection (CMW) of the Forestry and Agricultural Biotechnology Institute (FABI), University of Pretoria, South Africa. Ex-type isolates of the novel taxa were also deposited in the MUCL culture collection, Université Catholique de Louvain, Louvain-la-Neuve, Belgium. 
Table 1 - Isolates and sequences included in the present study.

\begin{tabular}{|c|c|c|c|c|c|c|c|c|c|c|c|c|}
\hline \multirow[t]{2}{*}{ OTU } & \multirow[t]{2}{*}{ New name } & \multirow[t]{2}{*}{ Old name } & \multirow[t]{2}{*}{$\begin{array}{l}\text { Cultured/ } \\
\text { Uncultured }\end{array}$} & \multirow{2}{*}{$\begin{array}{l}\text { Original } \\
\text { specimen } \\
\text { number }\end{array}$} & \multicolumn{2}{|c|}{ Isolate number ${ }^{a}$} & \multirow[t]{2}{*}{$\begin{array}{l}\text { PREM } \\
\text { number }\end{array}$} & \multirow[t]{2}{*}{ Isolated from } & \multirow[t]{2}{*}{ Origin } & \multicolumn{2}{|c|}{$\begin{array}{c}\text { GenBank accession } \\
\text { number }\end{array}$} & \multirow[t]{2}{*}{ Reference } \\
\hline & & & & & CMW & CBS/MUCL & & & & LSU & ITS & \\
\hline A & $\begin{array}{l}\text { Hawksworthiomyces } \\
\text { lignivorus }\end{array}$ & $\begin{array}{l}\text { Sporothrix } \\
\text { lignivora }\end{array}$ & Cultured & & 18597 & & 59287 & $\begin{array}{l}\text { Eucalyptus utility } \\
\text { poles planted in soil }\end{array}$ & South Africa & EF139117 & EF127887 & De Meyer et al. 2008 \\
\hline A & H. lignivorus & S. lignivora & Cultured & & 18598 & CBS 119146 & 59286 & $\begin{array}{l}\text { Eucalyptus utility } \\
\text { poles planted in soil }\end{array}$ & South Africa & EF139118 & EF127888 & De Meyer et al. 2008 \\
\hline A & H. lignivorus & S. lignivora & Cultured & & 18599 & CBS 119147 & 59285 & $\begin{array}{l}\text { Eucalyptus utility } \\
\text { poles planted in soil }\end{array}$ & South Africa & KX396545 & EF127889 & De Meyer et al. 2008 \\
\hline A & H. lignivorus & S. lignivora & Cultured & & 18600 & CBS 119148 & $59284^{\mathrm{T}}$ & $\begin{array}{l}\text { Eucalyptus utility } \\
\text { poles planted in soil }\end{array}$ & South Africa & EF139119 & EF127890 & De Meyer et al. 2008 \\
\hline A & H. lignivorus & S. lignivora & Cultured & & 18601 & CBS 119149 & 59283 & $\begin{array}{l}\text { Eucalyptus utility } \\
\text { poles planted in soil }\end{array}$ & South Africa & EF139120 & EF127891 & De Meyer et al. 2008 \\
\hline A & H. lignivorus & Sporothrix sp. & $\begin{array}{l}\text { Culture not } \\
\text { available }\end{array}$ & INBio2574B & & & & $\begin{array}{l}\text { Gut of wood-feeding } \\
\text { Scarabaeidae beetle } \\
\text { larvae }\end{array}$ & Costa Rica & & GU827484 & $\begin{array}{l}\text { Rojas-Jiminez } \\
\text { et al., unpubl. }\end{array}$ \\
\hline A & H. lignivorus & Sporothrix sp. & $\begin{array}{l}\text { Culture not } \\
\text { available }\end{array}$ & INBio2580B & & & & $\begin{array}{l}\text { Gut of wood-feeding } \\
\text { Scarabaeidae beetle } \\
\text { larvae }\end{array}$ & Costa Rica & & GU827495 & $\begin{array}{l}\text { Rojas-Jiminez } \\
\text { et al., unpubl. }\end{array}$ \\
\hline A & H. lignivorus & Sporothrix sp. & $\begin{array}{l}\text { Culture not } \\
\text { available }\end{array}$ & INBio3010E & & & & Gut of beetle larvae & Costa Rica & & HM770994 & $\begin{array}{l}\text { Rojas-Jiminez } \\
\text { et al., unpubl. }\end{array}$ \\
\hline A & H. lignivorus & Sporothrix sp. & $\begin{array}{l}\text { Culture not } \\
\text { available }\end{array}$ & INBio3715A & & & & Gut of beetle larvae & Costa Rica & & HM771021 & $\begin{array}{l}\text { Rojas-Jiminez } \\
\text { et al., unpubl. }\end{array}$ \\
\hline A & H. lignivorus & $\begin{array}{l}\text { Sporothrix sp. } \\
\text { TMS-2011 }\end{array}$ & Culture dead & Mbale 50-11 & & & & $\begin{array}{l}\text { Dead Miscanthus } \\
\text { giganteus material }\end{array}$ & USA, Illinois & & HQ630984 & Shresta et al. 2011 \\
\hline B & H. taylorii sp. nov. & This study & Cultured & & 20741 & MUCL 55927 & $61311^{\mathrm{T}}$ & $\begin{array}{l}\text { Eucalyptus utility } \\
\text { poles planted in soil }\end{array}$ & South Africa & KX396546 & KX396549 & This study \\
\hline B & H. taylorii sp. nov. & $\begin{array}{l}\text { Ascomycota sp. } \\
\text { AR-2010 }\end{array}$ & Culture dead & АT020 & & & & $\begin{array}{l}\text { Fungus garden } \\
\text { from Atta texana nest }\end{array}$ & USA, Texas & & HQ607793 & Rodrigues et al. 2011 \\
\hline C & $\begin{array}{l}\text { Hawksworthiomyces } \\
\text { sp. }\end{array}$ & $\begin{array}{l}\text { Uncultured soil } \\
\text { fungus clone } \\
\text { Indiana }\end{array}$ & uncultured & MOTU_LB5959 & & & & Deciduous forest soil & USA, Indiana & & KT197432 & Rosling et al. 2016 \\
\hline D & $\begin{array}{l}\text { Hawksworthiomyces } \\
\text { sp. }\end{array}$ & Leptographium sp. & $\begin{array}{l}\text { Culture } \\
\text { not available }\end{array}$ & INBio_45060 & & & & Passalidae beetle gut & Costa Rica & KM242324 & KM242324 & $\begin{array}{l}\text { Vargas-Asensio } \\
\text { et al. } 2014\end{array}$ \\
\hline D & $\begin{array}{l}\text { Hawksworthiomyces } \\
\text { sp. }\end{array}$ & Leptographium sp. & $\begin{array}{l}\text { Culture not } \\
\text { available }\end{array}$ & INBio_45116J & & & & Passalidae beetle gut & Costa Rica & KM242374 & KM242374 & $\begin{array}{l}\text { Vargas-Asensio } \\
\text { et al. } 2014\end{array}$ \\
\hline D & $\begin{array}{l}\text { Hawksworthiomyces } \\
\text { sp. }\end{array}$ & Leptographium sp. & $\begin{array}{l}\text { Culture not } \\
\text { available }\end{array}$ & INBio_4512I & & & & Passalidae beetle gut & Costa Rica & KM242349 & KM242349 & $\begin{array}{l}\text { Vargas-Asensio } \\
\text { et al. } 2014\end{array}$ \\
\hline D & $\begin{array}{l}\text { Hawksworthiomyces } \\
\text { sp. }\end{array}$ & Leptographium sp. & $\begin{array}{l}\text { Culture not } \\
\text { available }\end{array}$ & INBio_4513G & & & & Passalidae beetle gut & Costa Rica & KM242353 & KM242353 & $\begin{array}{l}\text { Vargas-Asensio } \\
\text { et al. } 2014\end{array}$ \\
\hline E & $\begin{array}{l}\text { Hawksworthiomyces } \\
\text { sp. }\end{array}$ & Leptographium sp. & $\begin{array}{l}\text { Culture not } \\
\text { available }\end{array}$ & INBio_4506N & & & & Passalidae beetle gut & Costa Rica & KM242323 & KM242323 & $\begin{array}{l}\text { Vargas-Asensio } \\
\text { et al. } 2014\end{array}$ \\
\hline E & $\begin{array}{l}\text { Hawksworthiomyces } \\
\text { sp. }\end{array}$ & Leptographium sp. & $\begin{array}{l}\text { Culture not } \\
\text { available }\end{array}$ & INBio_4507H & & & & Passalidae beetle gut & Costa Rica & KM242333 & KM242333 & $\begin{array}{l}\text { Vargas-Asensio } \\
\text { et al. } 2014\end{array}$ \\
\hline E & $\begin{array}{l}\text { Hawksworthiomyces } \\
\text { sp. }\end{array}$ & Leptographium sp. & $\begin{array}{l}\text { Culture not } \\
\text { available }\end{array}$ & INBio_4512G & & & & Passalidae beetle gut & Costa Rica & KM242347 & KM242347 & $\begin{array}{l}\text { Vargas-Asensio } \\
\text { et al. } 2014\end{array}$ \\
\hline
\end{tabular}




\begin{tabular}{|c|c|c|c|c|c|c|c|c|c|c|c|c|}
\hline $\mathrm{F}$ & $\begin{array}{l}\text { Hawksworthiomyces } \\
\text { sp. }\end{array}$ & Leptographium sp. & $\begin{array}{l}\text { Culture not } \\
\text { available }\end{array}$ & INBio_4515N & & & & Passalidae beetle gut & Costa Rica & KM242369 & KM242369 & $\begin{array}{l}\text { Vargas-Asensio } \\
\text { et al. } 2014\end{array}$ \\
\hline G & $\begin{array}{l}\text { Hawksworthiomyces } \\
\text { sp. }\end{array}$ & $\begin{array}{l}\text { Uncultured } \\
\text { root-associated } \\
\text { fungus clone }\end{array}$ & Uncultured & YL200c18P & & & & Yucca glauca roots & $\begin{array}{l}\text { USA, New } \\
\text { Mexico }\end{array}$ & & FJ362131 & Khidir et al. 2010 \\
\hline G & $\begin{array}{l}\text { Hawksworthiomyces } \\
\text { sp. }\end{array}$ & $\begin{array}{l}\text { Uncultured } \\
\text { root-associated } \\
\text { fungus clone }\end{array}$ & Uncultured & YL200c2P & & & & Yucca glauca roots & $\begin{array}{l}\text { USA, New } \\
\text { Mexico }\end{array}$ & & FJ362124 & Khidir et al. 2010 \\
\hline G & $\begin{array}{l}\text { Hawksworthiomyces } \\
\text { sp. }\end{array}$ & $\begin{array}{l}\text { Uncultured } \\
\text { root-associated } \\
\text { fungus clone }\end{array}$ & Uncultured & YL200c3P & & & & Yucca glauca roots & $\begin{array}{l}\text { USA, New } \\
\text { Mexico }\end{array}$ & & FJ362125 & Khidir et al. 2010 \\
\hline G & $\begin{array}{l}\text { Hawksworthiomyces } \\
\text { sp. }\end{array}$ & $\begin{array}{l}\text { Uncultured } \\
\text { root-associated } \\
\text { fungus clone }\end{array}$ & Uncultured & YL200c4P & & & & Yucca glauca roots & $\begin{array}{l}\text { USA, New } \\
\text { Mexico }\end{array}$ & & FJ362126 & Khidir et al. 2010 \\
\hline G & $\begin{array}{l}\text { Hawksworthiomyces } \\
\text { sp. }\end{array}$ & $\begin{array}{l}\text { Uncultured } \\
\text { root-associated } \\
\text { fungus clone }\end{array}$ & Uncultured & YL200c8P & & & & Yucca glauca roots & $\begin{array}{l}\text { USA, New } \\
\text { Mexico }\end{array}$ & & FJ362130 & Khidir et al. 2010 \\
\hline G & $\begin{array}{l}\text { Hawksworthiomyces } \\
\text { sp. }\end{array}$ & $\begin{array}{l}\text { Uncultured } \\
\text { root-associated } \\
\text { fungus clone }\end{array}$ & Uncultured & YL800c20P & & & & Yucca glauca roots & $\begin{array}{l}\text { USA, New } \\
\text { Mexico }\end{array}$ & & FJ362135 & Khidir et al. 2010 \\
\hline G & $\begin{array}{l}\text { Hawksworthiomyces } \\
\text { sp. }\end{array}$ & $\begin{array}{l}\text { Uncultured } \\
\text { root-associated } \\
\text { fungus clone }\end{array}$ & Uncultured & YL800c21P & & & & Yucca glauca roots & $\begin{array}{l}\text { USA, New } \\
\text { Mexico }\end{array}$ & & FJ362136 & Khidir et al. 2010 \\
\hline G & $\begin{array}{l}\text { Hawksworthiomyces } \\
\text { sp. }\end{array}$ & $\begin{array}{l}\text { Uncultured } \\
\text { root-associated } \\
\text { fungus clone }\end{array}$ & Uncultured & YL800c2P & & & & Yucca glauca roots & $\begin{array}{l}\text { USA, New } \\
\text { Mexico }\end{array}$ & & FJ362132 & Khidir et al. 2010 \\
\hline $\mathrm{H}$ & H. hibbettii sp. nov. & Sporothrix sp. & Cultured & TR071 & 37663 & $\begin{array}{l}\text { MUCL } \\
55929\end{array}$ & $61313^{\mathrm{T}}$ & $\begin{array}{l}\text { Fungus garden from } \\
\text { Trachymyrmex } \\
\text { septentrionalis nest }\end{array}$ & USA, Texas & KX396547 & $\begin{array}{l}\text { HQ608102; } \\
\text { KX396550 }\end{array}$ & Rodrigues et al. 2011 \\
\hline I & H. sequentia sp. nov. ENAS & $\begin{array}{l}\text { Uncultured } \\
\text { fungus clone }\end{array}$ & Uncultured & nik62104a_03C_19 & & & & $\begin{array}{l}\text { Picea abies log on } \\
\text { forest floor }\end{array}$ & Sweden & & HQ611296 ${ }^{\mathrm{T}}$ & Lindner et al. 2011 \\
\hline I & H. sequentia sp. nov. ENAS & Sporothrix sp. & Culture dead & WRCF-AW9 & & & & $\begin{array}{l}\text { Decayed Thuja } \\
\text { plicata fencepole }\end{array}$ & Canada, BC & & AY618685 & Lim et al. 2005 \\
\hline $\mathrm{J}$ & H. crousii sp. nov. & Sporothrix sp. & Cultured & KUC4053 & 37531 & $\begin{array}{l}\text { MUCL } \\
55928\end{array}$ & $61312^{\mathrm{T}}$ & $\begin{array}{l}\text { Decaying bamboo } \\
\text { chips }\end{array}$ & South Korea & KX396548 & $\begin{array}{l}\text { HM008928; } \\
\text { KX396551 }\end{array}$ & Kim et al. 2011 \\
\hline
\end{tabular}

$\mathrm{T}=$ type specimen or type sequence.

a CMW = culture collection of the Forestry and Agricultural Biotechnology Institute (FABI), University of Pretoria, South Africa; MUCL = Culture collection, Université Catholique de Louvain, Louvain-

la-Neuve, Belgium; CBS = Centraalbureau voor Schimmelcultures, Utrecht, The Netherlands; PREM = National Collection of Fungi (Herbarium), Pretoria, South Africa. 
Type specimens were deposited in the National Collection of Fungi (PREM), Pretoria, South Africa.

\section{DNA extraction, PCR, and DNA sequencing}

DNA was extracted following the methodology of Duong et al. (2012). The ribosomal LSU region was amplified and sequenced using primers LR3 and LR5 (White et al. 1990). The primer pair ITS1F (Gardes \& Bruns 1993) and ITS4 (White et al. 1990) was used for the ITS regions. PCR and sequencing protocols were as described by Duong et al. (2012), but modifications to annealing temperatures were made where needed.

\section{Phylogenetic analyses}

Data sets comprising sequences produced in the present study, together with reference sequences for the Ophiostomatales and the environmental sequences obtained from NCBI GenBank (Table 1), were compiled using MEGA 6.06 (Tamura et al. 2013). The two data sets (LSU, ITS) were aligned online in MAFFT 7 (Katoh \& Standley 2013), subjected to Gblocks 0.91b (Castresana 2000), and analysed [Maximum Likelihood (ML) and Bayesian Inference (BI)] as described by De Beer et al. (2016).

\section{Morphology}

Cultures were grown in $2 \%$ malt extract agar (MEA: $20 \mathrm{~g}$ malt extract, Biolab, South Africa; 25 g Difco agar, Becton, Dickinson and Company, USA) at room temperature. Slide cultures were prepared as described by De Meyer et al. (2008). Microscope slides were initially mounted in water that was later replaced with $85 \%$ lactic acid in which all the measurements and images were taken.

Microscopic features were studied using a Nikon Eclipse Ni compound microscope. Images were captured with a Nikon DS-Ri2 camera. The imaging software program NIS Elements BR (Nikon) was used to make measurements. Up to 50 measurements were made for characteristic features.

For the growth study, $5 \mathrm{~mm}$ mycelial plugs were prepared using a cork borer. The plugs were placed at the centres of $90 \mathrm{~mm}$ plates. Three replicates per isolate were incubated in the dark at six temperatures ranging from $10^{\circ} \mathrm{C}$ to $35^{\circ} \mathrm{C}$, at $5{ }^{\circ} \mathrm{C}$ intervals. After $14 \mathrm{~d}$, two diameter measurements were made for each colony at right angles to each other and averages were computed for comparisons.

\section{Results}

\section{Phylogenetic analyses}

The LSU and ITS data sets respectively consisted of 729 and 730 characters after alignment, and 696 and 485 characters after treatment with Gblocks. Analyses of the LSU region showed that the ex-type isolate of Sporothrix lignivora (Fig 1, Lineage A) formed a well-supported monophyletic lineage together with the three other isolates (Lineages $B$, $\mathrm{H}, \mathrm{J})$ sequenced in the present study from respectively South Africa, the USA, and South Korea. Sequences labelled as Leptographium sp. from Passalidae beetle guts in Costa Rica were also included in this lineage. Collectively, this lineage of seven sequences was completely distinct from all other genera in the Ophiostomatales, including Sporothrix as recently redefined by De Beer et al. (2016).

A greater number of ITS sequences related to S. lignivora were available from GenBank (Table 1) than for LSU. The well-supported lineage containing these sequences in the ITS tree (Fig 2) thus included 34 sequences. These separated into 10 lineages representing different MOTUs labelled as A-J (Fig 2). Lineage A included the ex-type and four additional isolates of S. lignivora from South Africa, as well as one sequence for an isolate from Miscanthus leaves in the USA, and four from the guts of wood-feeding Scarabaeidae beetles in Costa Rica (Table 1).

Lineages B, H, and J (Fig 2) included sequences obtained from isolates in the present study, grouping with sequences from GenBank (Table 1). Lineage B comprised the wooden pole isolate from South Africa (CMW 20741) together with a sequence from an isolate (now dead, A.R., pers. comm.) from the fungus garden of an Atta texana ant nest in Texas. Lineage $\mathrm{H}$ included two sequences of the same isolate, also from the fungus garden in Texas, but of a different ant species, Trachymyrmex septentrionalis. One sequence came from the original study Rodrigues et al. (2011), while the second sequence was produced in the present study to confirm the identity of the isolate. Similarly, Lineage J contained two sequences of a single isolate from bamboo in South Korea, one generated by Kim et al. (2011), and the other in the present study.

Lineages C and G (Fig 2) both consisted only of sequences from uncultured fungus clones in the USA, respectively from deciduous forest soil in Indiana and Yucca glauca roots in New Mexico (Table 1). Lineages D, E, and F all included sequences from isolates not available to us, from the guts of Passalidae beetles infesting decomposing logs in Costa Rica. These sequences were quite variable as is evident from Fig 2, but the isolates from which they were obtained also varied in culture morphology according to Vargas-Asensio et al. (2014).

Lineage I (Fig 2) included two sequences from different sources. One was of an uncultured fungus clone from a Picea abies log on a forest floor in Sweden, while the other was from an isolate (now dead) of a decayed Thuja plicata fencepole in Canada (Table 1). The two sequences comprised the complete ITS1, 5.8S, and ITS2 regions, differed only in two bp positions in a GC rich area of the ITS1 region, and did not include any ambiguous characters.

\section{Taxonomy}

Sequences of Sporothrix lignivora isolates, together with GenBank sequences obtained from uncultured fungus clones and isolates from nine different studies (Table 1), formed well-supported lineages in phylogenetic trees based on both the LSU and ITS data sets (Figs 1 and 2). This group clearly represents a distinct genus in the Ophiostomatales, which is described below. In addition, analyses of the ITS data (Fig 2) revealed at least ten well-supported sub-lineages. Based on standards applied to delineate species in other genera of the Ophiostomatales, we are confident that these lineages represent distinct species. Lineage A included what was formerly 
known as Sporothrix lignivora. We designate this taxon as the type species for the new genus and provide a new combination for it. For three lineages (B, $\mathrm{H}$, and $\mathrm{J}$ ) we had isolates from which type material could be prepared and they are described here as new species. Lineage I included two virtually identical sequences from different studies in different countries, supporting our hypothesis that this lineage represents a distinct species. In the absence of specimens, we designated one of the DNA sequences as type, and provide a species name for this taxon. Since the remaining lineages (C, D, E, F, G) each included only sequences from a single study, and no material was available for study, we chose not to assign binomials for them.

Hawksworthiomyces Z.W. de Beer, Marinc., M.J. Wingf. gen. nov.

MycoBank No.: MB815685

Etymology: Named for Dr David Hawksworth, in recognition of the leading role that he has played in guiding the global mycological community through the controversial and often challenging transition from a dual nomenclature to a one-fungus-one-name-based system.

Sexual state not observed. Asexual state mycelial, mononematous, micronematous or macronematous; conidiogenous cells polyblastic, integrated or discrete, terminal or intercalary, apical part bearing denticles; conidia hyaline, nonseptate, ellipsoidal to cylindrical, secondary conidia occasionally produced. Phylogenetic placement in Ophiostomatales, forming a monophyletic lineage distinct from all known genera based on LSU and ITS sequences.

Type species: Hawksworthiomyces lignivorus (de Mey., Z.W. de Beer, M.J. Wingf.) Z.W. de Beer, Marinc., M.J. Wingf. comb. nov.

\section{MycoBank No.: MB815686}

Synonym: Sporothrix lignivora de Mey., Z.W. de Beer, M.J. Wingf., Mycologia 100: 657. 2008. (basionym)

Specimens examined. South Africa. Western Cape Province: Stellenbosch. Isolated from Eucalyptus pole at soil level, Oct. 2003, E.M. de Meyer (HOLOTYPE, PREM 59284 dried culture, culture ex-holotype CMW $18600=$ CBS $119148=$ MUCL 55926). Same location, date, and collector (PREM 59283 dried culture, culture CMW18601 = CBS 119149; PREM 59285 dried culture, culture CMW 18599 = CBS 119147). KwaZulu-Natal: St Lucia. Isolated from Eucalyptus pole at soil level, May 2003, E.M. de Meyer (PREM 59286 dried culture, culture CMW18598 = CBS 119146; PREM 59287 dried culture, culture CMW 18597).

Hawksworthiomyces taylorii Z.W. de Beer, Marinc., M.J. Wingf. sp. nov. Fig 3A-C

MycoBank No.: MB815687

Etymology: Named for Dr John Taylor, recognising his visionary role in promoting the Article 59 debate, redefining fungal species concepts and making molecular taxonomy accessible to the broader mycological community.

Sexual state not observed. Asexual state: Conidiophores hyaline, mononematous, macronematous, cylindrical, upright, seldom branched, mostly reduced to conidiogenous cells. Conidiogenous cells polyblastic, integrated or discrete, terminal, cylindrical, slightly tapering toward apex, straight or curved, 4-32 $\mu \mathrm{m}$ long, $1.5-2.5 \mu \mathrm{m}$ wide at base, ending in fertile region usually located at $1 / 4$ upper part with denticles, or along the full length when cell is short, 3-14 $\mu \mathrm{m}$ long. Denticles minute, conical. Conidia hyaline, aseptate, diverse in various shapes from cylindrical to broadly ellipsoidal tapering towards base, base truncated, 3-6 $\times 1.5-3 \mu \mathrm{m}$ (avg. $4.3 \times 2.3 \mu \mathrm{m})$. Cultures circular with entire edge, medium dense, flat, texture velvety to cottony, no zonation, fertile, above dusky yellow-green with creamy patches at the centre, below evenly dark olivaceous green, optimum growth at $30{ }^{\circ} \mathrm{C}$, reaching $84.7 \mathrm{~mm}$ after $14 \mathrm{~d}$ in the dark, some degree of growth at $10-35^{\circ} \mathrm{C}$.

Specimen examined: South Africa. Western Cape Province: Stellenbosch. Isolated from Eucalyptus utility pole at soil level, Nov. 2005, E. M. de Meyer (HOLOTYPE, PREM 61311 dried culture, culture ex-holotype CMW 20741 = MUCL 55927).

Hawksworthiomyces hibbettii Z.W. de Beer, Marinc., M.J. Wingf. sp. nov. Fig 3D-F

MycoBank No.: MB815689

Etymology: Named for Dr David Hibbett, who has played a leading role in driving the process to reconcile naming systems for environmental versus culture-based species as well as to have the naming of sequence based-taxa accommodated in the Code.

Sexual state not observed. Asexual state: Conidiophores hyaline, mononematous, micro- or macro-nematous, simple or branched, often reduced to conidiogenous cells, 3-62 $\mu \mathrm{m}$ long, 1-2 $\mu \mathrm{m}$ wide at the base. Conidiogenous cells polyblastic, integrated or discrete, terminal or intercalary, cylindrical, straight or curved, 3-42 $\mu \mathrm{m}$ long, 1-2 $\mu \mathrm{m}$ wide at base, ending in fertile region with zig-zag growing denticles or occasionally swollen apex, $1.5-7 \mu \mathrm{m}$ long. Denticles distinct, short tubular, 0.5-2 $\mu \mathrm{m}$ long, $0.5-1.5 \mu \mathrm{m}$ wide at base, distance between denticles occasionally expanded showing zig-zag formation. Conidia hyaline, aseptate, shapes vary from cylindrical to ellipsoidal, tapering towards base, $3-5 \times 1.5-3 \mu \mathrm{m}$ (avg. $4.1 \times 2.2 \mu \mathrm{m})$. Cultures circular with entire edge, flat, smooth, velvety with few aerial hyphae, medium dense, no zonation, fertile, optimum growth at $30{ }^{\circ} \mathrm{C}$, reaching $58.5 \mathrm{~mm}$ in $14 \mathrm{~d}$ in the dark, above and below dusky yellow-green with a darker centre.

Specimen examined: USA. Texas: Bastrop County, Stengl 'Lost Pines' Biology Station. Isolated from fungus garden of Trachymyrmex septentrionalis (attine ant), 20 Apr. 2006, U. Mueller (HOLOTYPE, PREM 61313 dried culture, culture ex-holotype CMW 37663 = MUCL 55929).

Hawksworthiomyces crousii Z.W. de Beer, Marinc., M.J. Wingf. sp. nov. Fig 3G-J

MycoBank No.: MB815688

Etymology: Named for Dr Pedro Crous, one of the most prolific fungal taxonomists of all time, author of 3208 taxon names (including new species, new combinations, and genera) (www.Mycobank.org, accessed 30/06/2016), who conceived and hosted the momentous One Fungus One name meeting in Amsterdam. Also in recognition of the 'rebellious' role that he has played in applying one fungus 


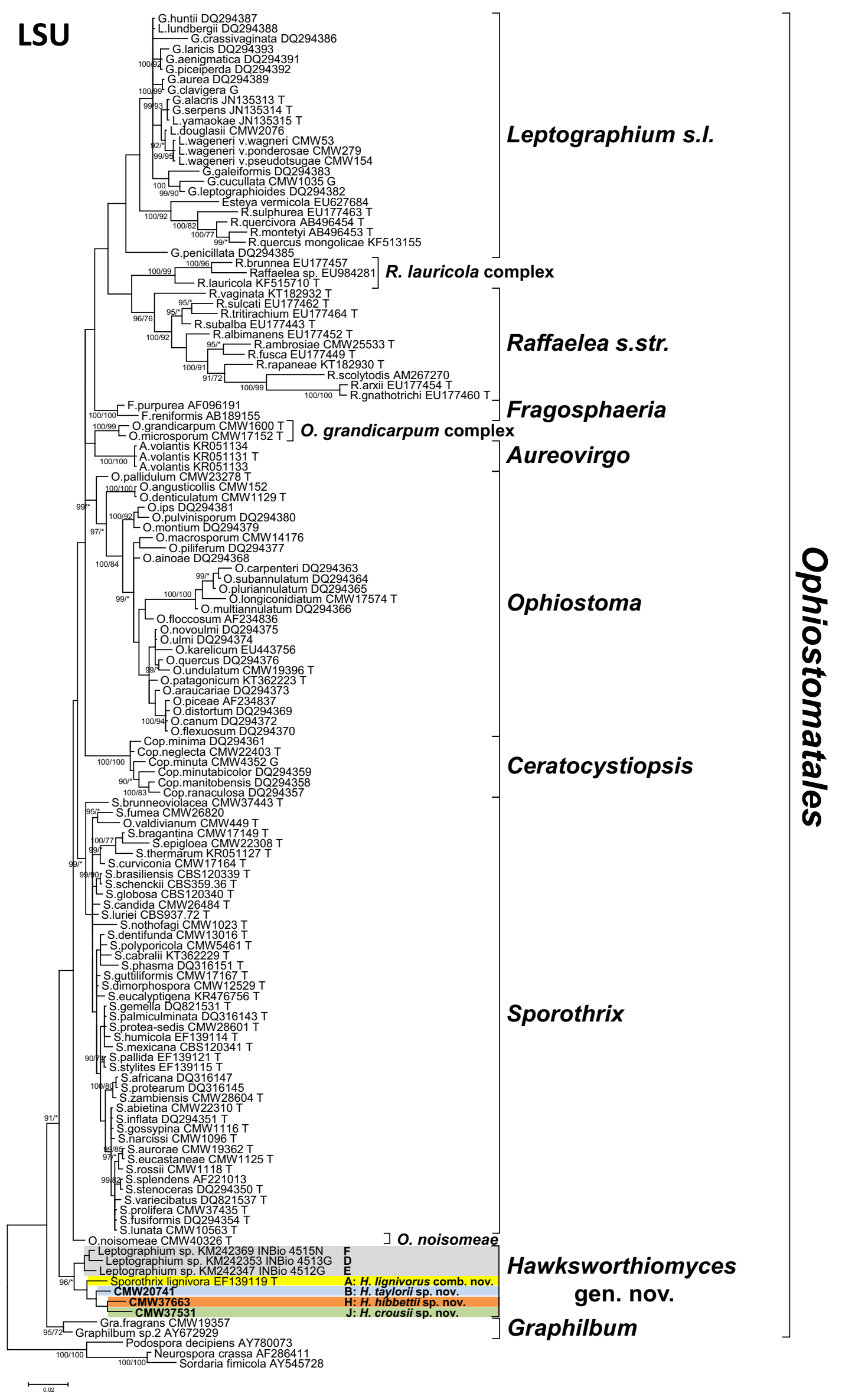




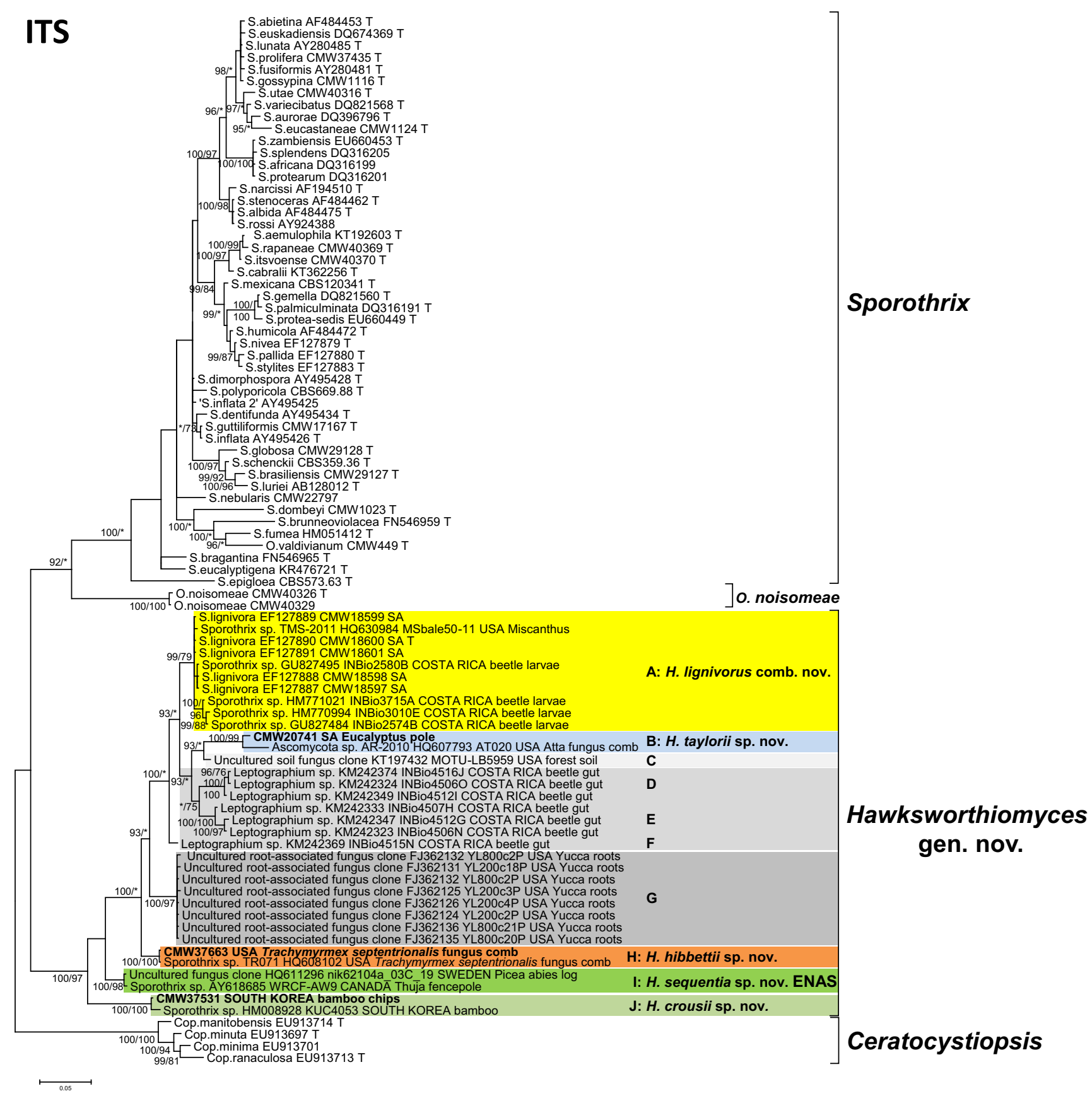

Fig 2 - Phylogram derived from Bayesian Inference (BI) analyses of ITS data (treated with Gblocks) of Sporothrix and Hawksworthiomyces spp. with Ceratocystiopsis as outgroup. Phylogenetic support is presented at nodes as Bayesian posterior probabilities $(>0.90 \%) / \mathrm{ML}$ bootstrap $(>70 \%)$. Sequences generated in the present study are printed in bold type.

one name principles in taxonomic papers many years before they were adopted in the Code.

Sexual state not observed. Asexual state: Conidiophores hyaline, mononematous, micro- or macro-nematous, cylindrical, simple or occasionally branched, upright, straight or curved, often reduced to conidiogenous cells, 6-69 $\mu \mathrm{m}$ long, 1-2 $\mu \mathrm{m}$ wide at the base. Conidiogenous cells polyblastic, integrated or discrete, terminal or intercalary, cylindrical, straight or curved, 5-22 $\mu \mathrm{m}$ long, generally ending in a swollen apex with denticles, fertile region occasionally showing extended growth beyond the apex, 1.5-9.5 $\mu \mathrm{m}$ long. Denticles distinct, short tubular or broadly conical,

Fig 1 - Phylogram derived from Bayesian Inference (BI) analyses of LSU data representative of all genera in the Ophiostomatales, treated with Gblocks. Phylogenetic support is presented at nodes as Bayesian posterior probabilities ( $>0.90 \%) / \mathrm{ML}$ bootstrap ( $>70 \%$ ). Sequences generated in the present study are printed in bold type. 

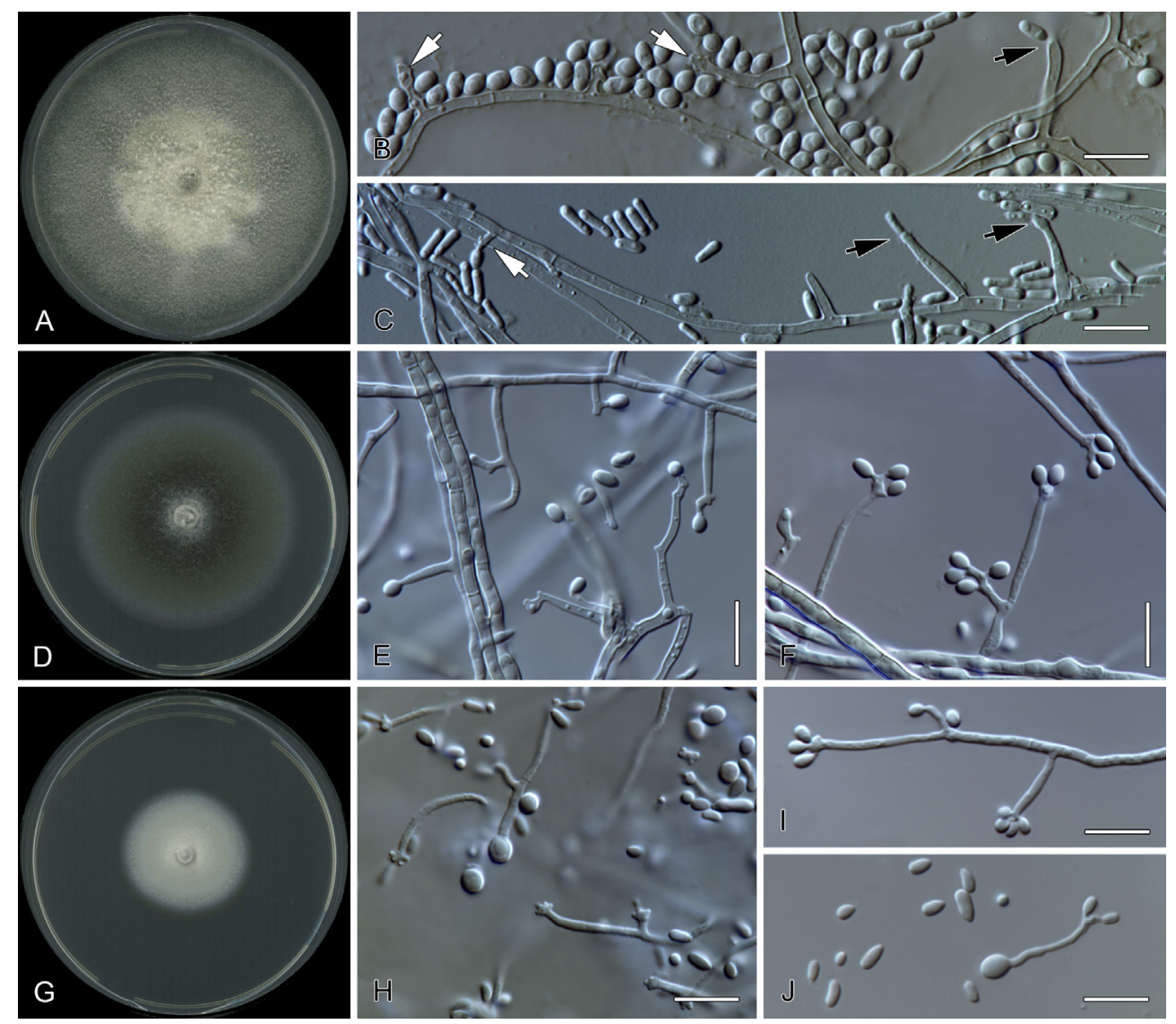

Fig 3 - (A-C). Hawksworthiomyces taylorii sp. nov. (CMW 20741 = MUCL 55927). (D-F). Hawksworthiomyces hibbettii sp. nov. (CMW 37663 = MUCL 55929). (G-J). Hawksworthiomyces crousii (CMW 37531 = MUCL 55928) sp. nov. (A, D, G). 14-day old cultures grown at $30^{\circ} \mathrm{C}$ in the dark. (B, C, E, F, H, I). Conidiogenous cells and conidia (white arrows indicating conidiogenous cells producing ellipsoidal conidia, black arrows cylindrical conidia). (J). Secondary conidia. Bars $=10 \mu \mathrm{m}$.

0.5-1 $\mu \mathrm{m}$ long, 0.5-1 $\mu \mathrm{m}$ wide at the base. Conidia hyaline, aseptate, diverse in shape varying from cylindrical to broadly ellipsoidal, tapering towards the base, base truncated, often producing secondary conidia, 3-6.5 $\times 1.5-3.5 \mu \mathrm{m}$ (avg. $4.5 \times 23 \mu \mathrm{m}$ ). Cultures circular with entire edge, dense, flat, smooth, with scarce aerial hyphae near edge, mycelium mostly submerged, no zonation, fertile, optimum growth at $30^{\circ} \mathrm{C}$, reaching $30.5 \mathrm{~mm}$ after $14 \mathrm{~d}$ in the dark, no growth at $10^{\circ} \mathrm{C}$, some degree of growth at $15-35^{\circ} \mathrm{C}$.

Specimen examined: South Korea: Seoul. Isolated from bamboo chips, 2003, J. J. Kim (HOLOTYPE, PREM 61312 dried culture, culture ex-holotype KUC 4053 = CMW $37531=$ MUCL 55928).

Hawksworthiomyces sequentia Z.W. de Beer, T.A. Duong, M.J. Wingf. sp. nov. ENAS

MycoBank No.: MB815690

Etymology: The epithet reflects the fact that this species is known only based on its DNA sequences.

Diagnosis: No extant specimen or culture. Represented by the least inclusive group containing organisms with nuclear rDNA sequences with GenBank accessions HQ611296 and AY618685. The suffix ENAS should always be used following the species name until such time as a specimen representing the species is designated as an epitype.
Reference phylogeny: Fig 2, present study.

Phylogenetic notes: Forms a distinct group, strongly supported as monophyletic (ML bootstrap $100 \%$, Bayesian posterior probabilities $=1.00$ ) within the genus Hawksworthiomyces (Fig 2, present study).

Type: Ribosomal ITS1, 5.8S, and ITS2 sequences, GenBank HQ611296=

tcattacagagttctcgcaactcccaaccctgtgaaccataccaaattttgttgttg cttctggcaggcggccctcgggctcctgccagcggcggcctgttccaaccttctt ttgtatcttaccgtctgagcttctaaaaaataaatcaaaactttcaacaacggatct cttggctctggcatcgatgaagaacgcagcgaaatgcgataagtaatgtgaattg cagaattcagtgaatcatcgaatctttgaacgcacattgcgcctgctagcattct ggcaggcatgcctgtccgagcgtcatttccaccctcacgctccgcgtggtgttga ggctctctcgcaacgagaggcccgaaagcgagtggcgggccgcctggttgg ctccgagcgcagtagaaacgcatgtttttttcc gctctggacgctgccggcgg tgcctgccgtcaaaacgcaccatgacgtgcaactttctcacaag (Lindner et al., Fungal Ecology 4: 449-460, 2011).

Locality, source, and date of type: Sweden: Fiby, old-growth Picea abies forest reserve (N 59"52.8640, E 17"21.1920), located approximately $15 \mathrm{~km}$ west of Uppsala. DNA extracted from wood shavings taken from an uninoculated Picea abies log, Jul. 2003.

Additional sequences included: GenBank AY618685 (Lim et al. 2005). Sequence similarity: $98.6 \%$ (ITS1), $100 \%$ (ITS2). 
Locality, source, and date of additional sequence: Canada: British Columbia, Vancouver. Decayed Western red cedar (Thuja plicata) fencepole, between 2001 and 2004.

Equivalent names: Uncultured fungus clone nik62104a_03C_19 (Lindner et al. 2011); Sporothrix sp. WRCF-AW9 (Lim et al. 2005).

Quality control: Chimera checker (Nilsson et al. 2010) results negative for both included sequences. Boundaries of rRNA regions identified with ITSx (Bengtsson-Palme et al. 2013) as follows:

AY618685: Length 514 bp. SSU: 1-31 ITS1: 32-175 5.8S: 176-333 ITS2: 334-514 LSU: Not found.

HQ611296: Length 534 bp. SSU: 1-53 ITS1: 54-197 5.8S: 198-355 ITS2: 356-534 LSU: Not found.

Ecological notes: The reference sequence was obtained as an uncultured fungus DNA clone extracted from an uninoculated Picea abies log placed (presumably on the ground) in an old-growth forest reserve in Sweden for a period of 6 years. This was part of a study to determine the fungal community development over time in these logs (Lindner et al. 2011). The second sequence is from a fungal isolate obtained from a decayed Western red cedar (Thuja plicata) fencepole in Vancouver, British Columbia (Lim et al. 2005). Unfortunately this isolate was lost (J.J.K., pers. comm.). Thus both sequences are from fungi present on relatively old decaying conifer wood in very different geographical locations but having similar climates.

\section{Morphological differences between the three specimen-based new species}

Apart from clear differences in DNA sequences, the three new species described based on specimens showed distinctly different culture morphologies (Fig 3) and growth rates (Fig 4). Hawksworthiomyces taylorii had the most rapid growth with dense aerial hyphae, while colonies of Hawksworthiomyces hibbettii were smooth with almost no aerial hyphae. All three species had optimum growth at $30^{\circ} \mathrm{C}$.

The denticles in three species were also distinct. Hawksworthiomyces taylorii has minute denticles often extending up

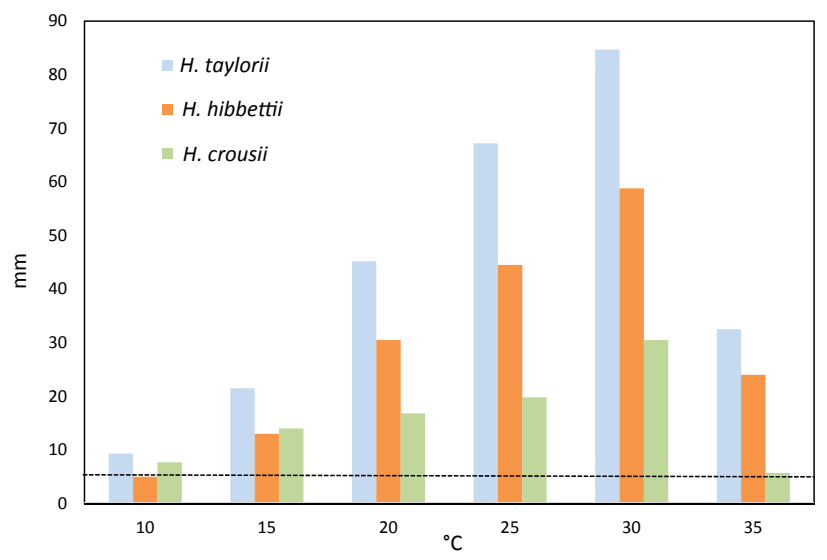

Fig 4 - Average growth of three new Hawksworthiomyces spp. on $2 \%$ MEA in the dark at $10-35{ }^{\circ} \mathrm{C}$ after $14 \mathrm{~d}$. Horizontal dotted line indicates the diameter of mycelial plug $5 \mathrm{~mm}$. to $1 / 4$ of the length of a conidiogenous cell, while $H$. hibbettii denticles commonly had swollen apices bearing clusters of denticles. Hawksworthiomyces crousii denticles were similar to those of $\mathrm{H}$. hibbettii, but commonly had larger denticles and a larger distance between denticles, resulting in an elongated fertile region.

\section{Discussion}

In this rather modest case study, we have incorporated environmental sequences into an otherwise straight forward, culture-based taxonomic revision where the initial aim was to determine the generic placement of a single, known species, Sporothrix lignivora. By including the environmental sequences, we were able to gain insights into the phylogenetic placement, species diversity, biology and possible ecological role of this group that would otherwise not have been possible. To achieve this goal, we had to confront the challenge of a Code that does not recognize or accommodate the fact that possibly millions of fungal species exist and for which we might never obtain specimens or cultures. We thus proceeded and were able to describe a new genus, Hawksworthiomyces, and three new species within the current confines of the Code. In naming the fourth species, known only from two ITS sequences from two independent studies, it was necessary to deviate from the current restrictions of the Code. In learning from this example and by providing some suggestions as to how to deal with similar situations, we hope to have initiated a process where the restrictive boundaries of the Code can be modified.

\section{The genus Hawksworthiomyces}

Earlier phylogenetic studies based on data obtained from fungal isolates, showed that the type species of Hawksworthiomyces lignivorus (=Sporothrix lignivora), does not group within any of the well-defined genera in the Ophiostomatales (De Beer \& Wingfield 2013). The inclusion of sequences of unidentified taxa from environmental studies in our phylogenetic analyses, revealed that this species forms part of a previously unrecognized genus including ten or more species. None of the studies from which the environmental sequences were obtained, nor previous phylogenies of the Ophiostomatales constructed only from specimen-based sequences, provided sufficient evidence for the delineation of this new genus. By contextualizing the environmental sequences within a specimen-based data set of named fungi, we were able to resolve the placement of the genus and to provide a classification for the unnamed environmental sequences.

Since its discovery, it has been clear that $\mathrm{H}$. lignivorus is not a typical ophiostomatalean fungus. By far the majority of the more than 300 known species in the Ophiostomatales are associated with bark or ambrosia beetles, infesting the cambium and sapwood of living, stressed or dying trees (De Beer \& Wingfield 2013). The only exception in the order is Sporothrix, as redefined by De Beer et al. (2016), that includes about 50 species from soil and Protea infructescences (Roets et al. 2013), as well the causal agents of human and animal sporotrichosis (Rodrigues et al. 2016). Hawksworthiomyces lignivorus was isolated in a survey of 
the causal agents of wooden utility pole decay in South Africa. These samples were taken from planted Eucalyptus poles with an increment borer at the soil level. Inoculation tests on wood blocks confirmed that isolates of this species cause significant decay when compared with other ascomycetes from the same survey that did not have any effect on the wood (De Beer et al. 2006). Other ophiostomatalean species are generally considered to be primary colonizers of freshly exposed wood (Kirisits 2004). They consequently have a restricted ability to degrade the lignocellulosic compounds in wood (Blanchette et al. 1992; Haridas et al. 2013).

When viewed peripherally, it might appear that the other sequences grouping in Hawksworthiomyces are of ecologically distinct and variable sources (Table 1). But upon closer inspection all of these sequences can be linked back to decaying wood or other plant material, and/or soil. For example, the fungi from guts of beetles were from larvae colonizing decomposing wood (Vargas-Asensio et al. 2014) and the fungus combs of Attine ants are composed of decaying plant material (Rodrigues et al. 2011). This is consistent with the known ecology of $\mathrm{H}$. lignivorus and it confirms that taxa residing in this genus indeed have a biology and probably ecological roles different to other fungi in the Ophiostomatales. We hypothesize that all the species of Hawksworthiomyces have wooddegrading capabilities. Furthermore, its basal position in the LSU tree (Fig 1) hints at the possibility that the sapwoodinfecting insect associates in the Ophiostomatales could have evolved from wood-decaying ancestors. This is a question that we intend to explore further.

The present study revealed that Hawksworthiomyces includes several species that are distributed across at least four continents. Five of these species now have names, while each of the remaining five lineages is represented by sequences of a single study. Following the recommendations of Hibbett et al. (2011), more isolates and/or sequences from additional, independent studies, will be needed in order to formally name them.

Most environmental sequences included in the present study were from taxa represented in low numbers in the studies where they were originally reported. These sequences would have remained part of long lists of unnamed MOTUs and statistics, if they had not been mined from GenBank with BLAST searches and included in our analyses. By including rather than ignoring them, our knowledge and understanding of the Ophiostomatales has been enriched.

\section{Challenges going forward}

This study has clarified the advantages of the naming of ENAS fungi and combining environmental sequences and specimenbased sequences to answer taxonomic, phylogenetic, and ecological questions. However, even though we had only to deal with 25 unnamed sequences, various challenges emerged. Many of these challenges were predicted and discussed in a published summary of the outcomes of the 2014 MSA workshop on sequence-based classification (Herr et al. 2015). Based on our experience from the present study and as a means of assisting future authors dealing with similar challenges, we provide brief comments below on some of these challenges and best practices discussed by Herr et al. (2015).
The database from which we obtained all sequences in the present study, was NCBI GenBank. Although we also made a search in the UNITE database (Köljalg et al. 2013), the same set of sequences were retrieved as those from GenBank. This can be explained by the fact that UNITE, like some other independent databases developed for specific community needs, largely draw on International Nucleotide Sequence Database Collaboration (INSDC).

In our study, the UNITE data set did not provide any more information than the data set obtained from GenBank. However, databases like UNITE should be seen as an additional layer of data to what is available, and have the potential to add great value to data in future as its online tools have become an option for annotation of public sequences, although it only addresses a single gene at this point (Nilsson et al. 2015). A major concern is that these and other international databases face serious challenges in terms of management, infrastructure, and funding resulting from the increased number of deposits (due to high throughput sequencing technologies) and size (whole genome sequences).

A serious problem that we faced is that third party annotation of sequences in these databases is not permitted. This implied that we could not update the records of sequences representing new taxa described in this study with the new names, if we did not generate those sequences ourselves. The 'old names' (Table 1) will thus persist in GenBank. A solution might be that if corrections are permitted, separate fields for 'Original name' and 'Current name' are established, similar to those available in Index Fungorum and MycoBank. We would also recommend the inclusion of the name of the person(s) who suggested the new name, and for the citation of the relevant publication. This will probably not occur easily and for the interim the solution must be to clearly list the old and new names in studies such as the present on (see Table 1, and Equivalent Names under Hawksworthiomyces sequentia ENAS). The utility for third party annotation that was recently made available by UNITE (Nilsson et al. 2015) is certainly a progression in the right direction.

The quality of sequences in public databases has been a concern for many years (Abarenkov et al. 2010; Nilsson et al. 2010, 2015). Hibbett et al. (2011) suggested that available software should be employed to ensure that the quality of sequences is verified before being used in any study, and especially before they are designated as Types. In the case of H. sequentia ENAS, we have determined the boundaries of rRNA regions using ITSx (Bengtsson-Palme et al. 2013) and we used a Chimera checker (Nilsson et al. 2010) to ensure the sequences were of good quality. There would be no need to be prescriptive regarding which software packages are used, particularly because other packages are likely to emerge over time.

Another challenge for databases lies in the capturing of metadata linked to sequences (Herr et al. 2015). As explained in Box 1, it was necessary for us to extract additional data from manuscripts. This can be achieved in the case of limited taxonomic studies. When naming ENAS fungi, it is thus important to capture that information in the formal species description, as we did for $H$. sequentia ENAS. A greater challenge is that public databases should set minimum requirements for metadata without which submitted data would not be accepted. 


\section{Box 1}

Notes on the naming, typification, and format of the description of ENAS taxa.

In the description of Hawksworthiomyces sequentia ENAS, we generally followed the format that was suggested by Hibbett et al. (2011) and adapted by Hawksworth et al. (2011), but with some modification and re-arrangement of sections. These modifications are discussed below. In terms of format, the recommended fields should be stipulated and a template can be provided, perhaps on the MycoBank website. However, as is current practice, journals should be allowed to determine the final format.

\section{Naming species}

In the example provided by Hawksworth et al. (2011), the species name was followed only by the customary 'sp. nov.', and in a footnote they mentioned two suffixes that might be used in conjunction with such names: 'Candidatus' as applied by the bacteriologists for the same concept, or 'ENAS', acronym for Environmental Nucleic Acid Sequence, a term introduced by Taylor (2011). In his presentation at IMC 10 in Thailand in 2014, David Hibbett presented a fourth possibility. This was to use a 'nom. prov.', acronym for nomen provisorium or provisional name.

We chose ENAS as suffix because it is clear what it represents. We suggest that it should always be used following the epithet (e.g. H. sequentia Z.W. de Beer, T.A. Duong, M.J. Wingf. ENAS, or H. sequentia ENAS). This would facilitate immediate distinction between specimen-based and sequence based-taxa. The suffix should follow the epithet, and the authorities where applicable, which will allow alphabetic sorting based on genus name first, followed by epithet, as is custom in lists generated by databases like MycoBank, Index Fungorum, and others. It is thus recommended that these repositories will make provision for the addition of the suffix and that it displays in all records together with the species name. However, once an isolate or specimen representing the species is discovered and designated as epitype, the ENAS suffix can be dropped.

We initially considered using nom. prov. (nomen provisorium or provisional name), but this could result in confusion. Nom. prov. is often used in other contexts, e.g. where a new species or genus description is presented prior to publication at a congress or in student theses. We believe that it is best to avoid multiple interpretations or applications of such a term. Furthermore, Art. 36.1(b) clearly states that a 'so-called provisional name' is not validly published because 'it is merely proposed in anticipation of the future acceptance of the taxon concerned' (McNeill et al. 2012). A provisional name is consequently fundamentally different from a valid name for a species known only based on sequence data.

Candidatus, as is used by the bacteriologists, could work for fungi. But it would not be applicable as a prefix for two reasons. One problem is that such a Latinized term preceding a genus name would confuse non-taxonomists. It would also create problems during automated alphabetic sorting in electronic databases and lists. Furthermore, it is our opinion that Candidatus is not as self-explanatory as ENAS.

\section{Naming genera and higher rank taxa}

In the present study, the type species, Hawksworthiomyces lignivorus, of the newly described genus is typified by a specimen, resulting in the new genus name being treated consistent with and valid under the Melbourne Code. We suggest that a recommendation is made that any genus that includes a combination of ENAS and specimen-based species, is typified by a specimen-based species. However, in cases where no specimen-based species can be included in a genus or higher rank taxon, the ENAS suffix can be used in a similar way as for species (e.g. Hibbettiana Authors gen. nov. ENAS, upon first use, or Hibbettiana ENAS when used without authorities). Again, using ENAS as a suffix will facilitate alphabetical sorting of these taxa.

\section{Typification}

Hawksworth et al. (2011) distinguished between a Nucleic Acid Type (the GenBank accession number and citation) and a Nomenclatural Sample. They suggested that the latter category could be a sample of extracted DNA, or part of the original environmental sample, e.g. Soil. However, if the Nomenclatural Sample were to become a requirement for valid publication of an ENAS species name, it would not be possible to name species such as $H$. sequentia ENAS described in the present study. The reason is that no extant material from which the DNA was originally obtained, exists from either of the two studies in which the sequences were produced. The original material respectively consisted of wood shavings (Lindner et al. 2011) and an isolate (Kim et al. 2011). This will certainly be a common and widespread problem, because the inclusion of environmental sequences in phylogenetic studies and the naming of ENAS species could occur many years after the initial publication of the sequences. The large numbers of specimens or isolates obtained in fungal ecology studies 


\section{Box 1 (continued)}

are often maintained uncurated only for the duration of the project. Furthermore, it would not make sense to simply circumvent the Code by depositing a symbolic or fake specimen, e.g. a tube of soil, if there is no guarantee that some DNA of the relevant species survives intact in the specimen. Our suggestion is thus that the requirement for a Nomenclatural Sample should be omitted, but a recommendation can be included encouraging the submission of a sample (DNA or e.g. soil).

Considering a Nomenclatural Type, Articles 8.1 and 40.5 of the Code (McNeill et al. 2012) allows for the designation of an illustration that shows a unique character of the fungus. As early as 1991, Reynolds \& Taylor (1991) suggested that 'a diagrammatic depiction' of 'a specific sequence of DNA nucleotide bases' could technically serve as a type. They further suggested that the Code should make a distinction between a 'DNA type', which would be the equivalent of the above-mentioned Nucleic Acid Type, and a Morphological Type. However, to present some form of diagram or illustration of a DNA sequence, would again seek to circumvent the Code, rather than to correct it. We recommend that the Code rather be emended to allow a DNA sequence as Type, in addition to the currently available options to deposit a specimen or illustration as types.

There could be a recommendation that an ITS sequence, as the accepted fungal barcode (Schoch et al. 2012) and the marker most often used in DNA-based environmental surveys, is used as Type. However, the ITS has been shown as problematic when seeking to distinguish species in some fungal groups (Seifert 2009; Naidoo et al. 2013). For this reason, a secondary barcode has already been suggested (Stielow et al. 2015), but in some fungus groups other gene regions might be preferable. The Code should thus not be prescriptive regarding the gene region to be used as the Type.

We suggest that when a DNA sequence is designated as Type, the Type section in descriptions includes the (1) name of the gene region, (2) a GenBank accession number, (3) the full sequence, and (4) the citation of the source of the sequence. Parts 1 , 2 , and 4 should be required, while part 3 should be a recommendation. If the Code adopts the concept of a DNA sequence as Type and the GenBank accession number as reference to it, the requirement of Art. 40.6 (McNeill et al. 2012) that the type be explicitly indicated in the protologue, would also be met.

\section{Diagnosis}

For the diagnosis of Hawksworthiomyces sequentia ENAS we followed the format suggested by Hawksworth et al. (2011) that defined a species based on the least inclusive phylogenetic group containing two or more sequences representing the taxon in question. However, in a request for a binding decision on the descriptive statements of two species described earlier in a similar way [Mortierella sigyensis K. Voigt, P.M. Kirk \& Bridge (Bridge \& Hughes 2012) and Piromyces cryptodigmaticus Fliegerová, K. Voigt \& P.M. Kirk (Kirk 2012)], Tripp \& Lendemer (2012) suggested that it is not clear whether such descriptions (i.e. those similar to only the second sentence of the $H$. sequentia ENAS diagnosis) meet the qualifications for effective description or diagnosis outlined in the Melbourne Code. Art. 38.1(a) states that 'in order to be validly published, a name of a taxon ... must be accompanied by a description or diagnosis,' while Art. 38.3 states that 'the requirements of Art. 38.1(a) are not met by statements describing properties such as purely aesthetic features, economic, medicinal or culinary use, cultural significance, cultivation techniques, geographical origin, or geological age' (McNeill et al. 2012). Tripp \& Lendemer (2012) argued that the presentation of features distinguishing new taxa from close relatives convey only relationships (and thus 'properties') and not how sequence data of the new taxa differ from those of related species. Secondly, they questioned the fact that both descriptions relied 'on external data (i.e., sequence data contained in GenBank, but not presented in the protologue) to distinguish the new taxa' (Tripp \& Lendemer 2012). The authors concluded that for sequence-based descriptions, an explicit statement of differences at homologous nucleotide positions should be presented to meet the requirements for effective description (Tripp \& Lendemer 2012).

In an attempt to accommodate the suggestions by Tripp \& Lendemer (2012), we studied the aligned data set of ITS sequences of the four specimen-based species of Hawksworthiomyces and H. sequentia ENAS (Supplementary Fig S1), to identify 'differences at homologous nucleotide positions' that could be listed as part of the diagnosis. However, after careful consideration we opted not to include these differences in the diagnosis for the following reasons. (1) The unique positions for a species largely depend on the available sequences of other species with which it is compared, and thus will most likely change when new isolates/species are added to the complex. (2) Identifying unique positions of a species is prone to error, especially in the ambiguous regions of the alignment such as non-coding (i.e. the ITS) and intragenic regions. For these reasons we suggest that rather than including the differences at homologous nucleotide positions in the description as suggested by Tripp \& Lendemer (2012), the complete sequence should be presented either as part of the description or under the Type section as was done above.

\section{Metadata linked to the type and additional sequences}

We have expanded the suggested heading Locality of reference sequence, to Locality, source, and date of reference sequence. This is to align the ENAS description with those of specimen-based species (see examples above) and to ensure that as much 


\section{Box 1 (continued)}

metadata as is available is provided for the new taxon. These data are often not captured in the sequence records in GenBank or other databases. A case in point from this study is Hawksworthiomyces sequentia ENAS, where the information would then need to be extracted from the original publication. These details are most valuable in making inferences regarding the biology, ecology or geographic distribution of the relevant taxa.

Also consistent with specimen-based descriptions, we have added a heading Locality, source, and date of additional sequence(s). Again, this is to ensure that as much of the metadata as possible relating to the other sequences are captured, because this was also not available in the GenBank record of the second sequence of $H$. sequentia ENAS.

Species recognition and taxon delimitation varies between different studies and groups of fungi. This could be a challenge in studies including ENAS fungi. Although community standards would be desirable (e.g. Vellinga et al. 2015), absolute standards for all groups will not be practical (Herr et al. 2015). In the present study we delimited species based on statistically supported phylogenetic lineages in ITS trees (Fig 2). As with many other fungal groups, genealogical concordance using ITS sequences together with those from other unlinked loci, has become the norm when delimiting species in the Ophiostomatales (Grobbelaar et al. 2009; Linnakoski et al. 2010; Roets et al. 2010; Duong et al. 2012; Yin et al. 2015, 2016). Drawing from our experience in using the ITS in conjunction with other gene regions, we are confident that our conclusions are sound. This should probably be the recommended approach for future taxonomic studies including ENAS fungi. But this approach will clearly not be possible where completely novel higher rank lineages of fungi are discovered and described based only on ITS sequences.

Vellinga et al. (2015) proposed some guidelines for introducing new genera of fungi. Several of these criteria (numbered in parentheses) can and should be met when ENAS genera are described, but in many such studies meeting all of these requirements will be challenging. In the case of Hawksworthiomyces all major genera of Ophiostomatales in the LSU phylogeny formed (1) well-supported, (2) monophyletic lineages (Fig 1), and (3) the coverage of the tree was broad, including all known taxa in the new genus, sufficient numbers of taxa, the type species of all related genera, and a broad geographical range from where taxa originated. Furthermore, we considered (4) all supporting evidence and background information of all the taxa grouping in Hawksworthiomyces. (5) Different methods for phylogenetic analyses were employed, all of which showed Hawksworthiomyces as forming a distinct, monophyletic lineage. However, the suggested (6) addition of protein coding gene sequences in addition to ribosomal gene regions were not possible, as most environmental studies rely on ITS and/or LSU data. In some ENAS studies, it might also be difficult to achieve (3) broad coverage or (4) to obtain background information about taxa. The aim should be to follow the guidelines of Vellinga et al. (2015) as far as possible, but with the understanding that in most ENAS studies one or more of these will not be achievable.

\section{Conclusions}

After having successfully addressed the challenge of emending the Code the mycological community should now face up to and act on another important reality. This is that thousands, if not millions of fungal species might forever be known only based on their DNA sequences. Failing to accommodate them in the Code and providing them with real names, equates to ignoring their existence. The question is no longer whether this must be done, but how it should be achieved. We have provided a clear example of a logical way forward.

Taylor (2011) suggested two steps towards gaining acceptance of the description of fungi based only on DNA sequences. The first 'would be a published demonstration of the naming of ENAS (environmental nucleic acid sequence) fungi, echoing the ... social activism' that preceded the abandonment of dual nomenclature in Melbourne. The present study could be seen by some as such a demonstration. The second step and the more complex problem according to Taylor (2011), will be gaining the acceptance of named ENAS fungi by the Code. Many papers have called for action (Hibbett et al. 2009, 2011; Hawksworth et al. 2011; Hibbett \& Glotzer 2011; Taylor 2011; Hibbett \& Taylor 2013; Taylor \& Hibbett 2013; Herr et al. 2015). Yet no concrete action has been taken and a formal proposal for changes to the Code has still not emerged. This will occur only with the support of the larger mycological community. We call for action to be taken now.

\section{Acknowledgements}

We are grateful to Dr Hugh Glen for advice on providing appropriate Latin names for the new genus and species. We also acknowledge funding from the National Research Foundation, members of the Tree Protection Cooperative Programme (TPCP) and the DST/NRF Centre of Excellence in Tree Health Biotechnology (CTHB), South Africa.

\section{Appendix A. Supplementary data}

Supplementary data related to this article can be found at http://dx.doi.org/10.1016/j.funbio.2016.07.004.

\section{R E F E R E N C E S}

Abarenkov K, Nilsson RH, Larsson K-H, Alexander IJ, Eberhardt U, Erland S, Høiland K, Kjøller R, Larsson E, Pennanen T, Sen R, Taylor AFS, Tedersoo L, Ursing BM, Vrålstad T, Liimatainen $\mathrm{K}$, Peintner U, Kõljalg U, 2010. The UNITE database for molecular 
identification of fungi - recent updates and future perspectives. New Phytologist 186: 281-285.

Bengtsson-Palme J, Ryberg M, Hartmann M, Branco S, Wang Z, Godhe A, De Wit P, Sánchez-García M, Ebersberger I, de Sousa F, Amend A, Jumpponen A, Unterseher M, Kristiansson E, Abarenkov K, Bertrand YJK, Sanli K, Eriksson KM, Vik U, Veldre V, Nilsson RH, 2013. Improved software detection and extraction of ITS1 and ITS2 from ribosomal ITS sequences of fungi and other eukaryotes for analysis of environmental sequencing data. Methods in Ecology and Evolution 4: 914-919.

Berbee ML, Taylor JW, 1992. 18s Ribosomal RNA gene sequence characters place the pathogen Sporothrix schenckii in the genus Ophiostoma. Experimental Mycology 16: 87-91.

Blackwell M, 2011. The fungi: 1, 2, 3... 5.1 million species? American Journal of Botany 98: 426-438.

Blanchette RA, Farrell RL, Barnes JA, Wendler PA, Zimmerman W, Brush TS, Snyder RA, 1992. Biological control of pitch in pulp and paper production by Ophiostoma piliferum. Tappi Journal 75 : 102-106.

Bridge PD, Hughes KA, 2012. Nomenclatural novelties. Index Fungorum 1: 1.

Castresana J, 2000. Selection of conserved blocks from multiple alignments for their use in phylogenetic analysis. Molecular Biology and Evolution 17: 540-552.

De Beer ZW, De Meyer EM, Dhaver K, 2006. Research Report (RES/RR/05/26611) on Wood Pole Research for Eskom Holdings (Ltd). FABI, University of the Pretoria, Pretoria, South Africa.

De Beer ZW, Duong TA, Wingfield MJ, 2016. The divorce of Sporothrix and Ophiostoma: solution to a problematic relationship. Studies in Mycology. http://dx.doi.org/10.1016/j.simyco.2016.07.001.

De Beer ZW, Seifert KA, Wingfield MJ, 2013. A nomenclator for ophiostomatoid genera and species in the Ophiostomatales and Microascales. In: Seifert KA, De Beer ZW, Wingfield MJ (eds), The Ophiostomatoid Fungi: expanding frontiers. CBS-KNAW Fungal Biodiversity Centre, Utrecht, The Netherlands, pp. 245-322.

De Beer ZW, Wingfield MJ, 2013. Emerging lineages in the Ophiostomatales. In: Seifert KA, De Beer ZW, Wingfield MJ (eds), The Ophiostomatoid Fungi: expanding frontiers. CBS, Utrecht, The Netherlands, pp. 21-46.

De Meyer EM, De Beer ZW, Summerbell RC, Moharram AM, De Hoog GS, Vismer HF, Wingfield MJ, 2008. Taxonomy and phylogeny of new wood- and soil-inhabiting Sporothrix species in the Ophiostoma stenoceras-Sporothrix schenckii complex. Mycologia 100: 647-661.

Duong TA, De Beer ZW, Wingfield BD, Wingfield MJ, 2012. Phylogeny and taxonomy of species in the Grosmannia serpens complex. Mycologia 104: 715-732.

Gardes M, Bruns TD, 1993. ITS primers with enhanced specificity for Basidiomycetes - application to the identification of mycorrhizae and rusts. Molecular Ecology 2: 113-118.

Grobbelaar J, Aghayeva D, De Beer ZW, Bloomer P, Wingfield MJ, Wingfield BD, 2009. Delimitation of Ophiostoma quercus and its synonyms using multiple gene phylogenies. Mycological Progress 8: 221-236.

Haridas S, Wang Y, Lim L, Massoumi Alamouti S, Jackman S, Docking R, Robertson G, Birol I, Bohlmann J, Breuil C, 2013. The genome and transcriptome of the pine saprophyte Ophiostoma piceae, and a comparison with the bark beetle-associated pine pathogen Grosmannia clavigera. BMC Genomics 14: 373.

Hawksworth DL, 2001. The magnitude of fungal diversity: the 1.5 million species estimate revisited. Mycological Research 105: 1422-1432.

Hawksworth DL, Crous PW, Redhead SA, Reynolds DR, Samson RA, Seifert KA, Taylor JW, Wingfield MJ, Abaci Ö, Aime C, Asan A, Bai F-Y, De Beer ZW, Begerow D, Berikten D, Boekhout T, Buchanan PK, Burgess T, Buzina W, Cai L, Cannon PF, Crane JL, Damm U, Daniel H-M, Van
Diepeningen AD, Druzhinina I, Dyer PS, Eberhardt U, Fell JW, Frisvad JC, Geiser DM, Geml J, Glienke C, Gräfenhan T, Groenewald JZ, Groenewald M, De Gruyter J, GuéhoKellermann E, Guo L-D, Hibbett DS, Hong S-B, De Hoog GS, Houbraken J, Huhndorf SM, Hyde KD, Ismail A, Johnston PR, Kadaifciler DG, Kirk PM, Kõljalg U, Kurtzman CP, Lagneau PE, Lévesque CA, Liu X, Lombard L, Meyer W, Miller AN, Minter DW, Najafzadeh NJ, Norvell L, Ozerskaya SM, Öziç R, Pennycook SR, Peterson SW, Pettersson OV, Quaedvlieg W, Robert VA, Ruibal C, Schnürer J, Schroers HJ, Shivas R, Slippers B, Spierenburg H, Takashima M, Taşkın E, Thines M, Thrane U, Uztan AH, Van Raak M, Varga J, Vasco A, Verkley GJM, Videira SIR, De Vries RP, Weir BS, Yilmaz N, Yurkov A, Zhang N, 2011. The Amsterdam declaration on fungal nomenclature. IMA Fungus 2: 105-112.

Herr JR, Opik M, Hibbett DS, 2015. Towards the unification of sequence-based classification and sequence-based identification of host-associated microorganisms. New Phytologist 205: 27-31.

Hibbett D, 2016. The invisible dimension of fungal diversity. Science 351: 1150-1151.

Hibbett DS, Glotzer D, 2011. Where are all the undocumented fungal species? A study of Mortierella demonstrates the need for sequence-based classification. New Phytologist 191: 592-596.

Hibbett DS, Ohman A, Glotzer D, Nuhn M, Kirk P, Nilsson RH, 2011. Progress in molecular and morphological taxon discovery in Fungi and options for formal classification of environmental sequences. Fungal Biology Reviews 25: 38-47.

Hibbett DS, Ohman A, Kirk PM, 2009. Fungal ecology catches fire. New Phytologist 184: 279-282.

Hibbett DS, Taylor JW, 2013. Fungal systematics: is a new age of enlightenment at hand? Nature Reviews Microbiology http: //dx.doi.org/10.1038/nrmicro2942.

Issakainen J, 1999. Dear Mr Code. Taxon 48: 341-348.

Katoh K, Standley DM, 2013. MAFFT multiple sequence alignment software version 7: improvements in performance and usability. Molecular Biology and Evolution 30: 772-780.

Khidir HH, Eudy DM, Porras-Alfaro A, Herrera J, Natvig DO, Sinsabaugh RL, 2010. A general suite of fungal endophytes dominate the roots of two dominant grasses in a semiarid grassland. Journal of Arid Environments 74: 35-42.

Kim J-J, Lee S-S, Ra J-B, Lee H, Huh N, Kim G-H, 2011. Fungi associated with bamboo and their decay capabilities. Holzforschung 65: 271-275.

Kirisits T, 2004. Fungal associates of European bark beetles with special emphasis on the Ophiostomatoid fungi. In: Lieutier F, Day KR, Battisti A, Grégoire J-C, Evans H (eds), Bark and Wood Boring Insects in Living Trees in Europe, a Synthesis. Kluwer Academic Publishers, Dordrecht, pp. 181-235.

Kirk PM, 2012. Nomenclatural novelties. Index Fungorum 1: 1.

Kõljalg U, Nilsson RH, Abarenkov K, Tedersoo L, Taylor AFS, Bahram M, Bates ST, Bruns TD, Bengtsson-Palme J, Callaghan TM, Douglas B, Drenkhan T, Eberhardt U, Dueñas M, Grebenc T, Griffith GW, Hartmann M, Kirk PM, Kohout P, Larsson E, Lindahl BD, Lücking R, Martín MP, Matheny PB, Nguyen NH, Niskanen T, Oja J, Peay KG, Peintner U, Peterson M, Põldmaa K, Saag L, Saar I, Schüßler A, Scott JA, Senés C, Smith ME, Suija A, Taylor DL, Telleria MT, Weiss M, Larsson K-H, 2013. Towards a unified paradigm for sequence-based identification of fungi. Molecular Ecology 22: 5271-5277.

Lim Y, Kim J-J, Chedgy R, Morris P, Breuil C, 2005. Fungal diversity from western redcedar fences and their resistance to $\beta$-thujaplicin. Antonie van Leeuwenhoek 87: 109-117.

Lindner DL, Vasaitis R, Kubartová A, Allmér J, Johannesson H, Banik MT, Stenlid J, 2011. Initial fungal colonizer affects mass loss and fungal community development in Picea abies logs 6 yr after inoculation. Fungal Ecology 4: 449-460. 
Linnakoski R, De Beer ZW, Ahtiainen J, Sidorov E, Niemelä P, Pappinen A, Wingfield MJ, 2010. Ophiostoma spp. associated with pine and spruce-infesting bark beetles in Finland and Russia. Persoonia 25: 72-93.

McNeill J, Barrie FR, Buck WR, Demoulin V, Greuter W, Hawksworth DL, Herendeen PS, Knapp S, Marhold K, Prado J, Prud'homme van Reine WF, Smith GF, Wiersema JH, Turland NJ, 2012. International Code of Nomenclature For Algae, Fungi, And Plants (Melbourne Code). Regnum Vegetabile 154. ARG Gantner Verlag KG.

Menkis A, Urbina H, James TY, Rosling A, 2014. Archaeorhizomyces borealis sp. nov. and a sequence-based classification of related soil fungal species. Fungal Biology 118: 943-955.

Mueller G, Schmit J, 2007. Fungal biodiversity: what do we know? What can we predict? Biodiversity and Conservation 16: 1-5.

Naidoo K, Steenkamp ET, Coetzee MPA, Wingfield MJ, Wingfield BD, 2013. Concerted evolution in the ribosomal RNA cistron. PLoS One 8: e59355.

Nilsson RH, Abarenkov K, Veldre V, Nylinder S, De Wit P, BroschÉ S, Alfredsson JF, Ryberg M, Kristiansson E, 2010. An open source chimera checker for the fungal ITS region. Molecular Ecology Resources 10: 1076-1081.

Nilsson RH, Tedersoo L, Ryberg M, Kristiansson E, Hartmann M, Unterseher M, Porter TM, Bengtsson-Palme J, Walker DM, De Sousa F, Gamper HA, Larsson E, Larsson KH, Koljalg U, Edgar RC, Abarenkov K, 2015. A comprehensive, automatically updated fungal ITS sequence dataset for reference-based chimera control in environmental sequencing efforts. Microbes and Environments 30: 145-150.

O’Brien HE, Parrent JL, Jackson JA, Moncalvo J-M, Vilgalys R, 2005. Fungal community analysis by large-scale sequencing of environmental samples. Applied and Environmental Microbiology 71: 5544-5550.

Öpik M, Davison J, Moora M, Zobel M, 2014. DNA-based detection and identification of Glomeromycota: the virtual taxonomy of environmental sequences. Botany-Botanique 92: 135-147.

Redhead SA, Demoulin V, Hawksworth DL, Seifert KA, Turland NJ, 2014. Fungal nomenclature at IMC10: report of the nomenclature sessions. IMA Fungus 5: 449-462.

Reynolds DR, Taylor JW, 1992. Article 59: reinterpretation or revision? Taxon 41: 91-98.

Rosling A, Midgley MG, Cheeke T, Urbina H, Fransson P, Phillips RP, 2016. Phosphorus cycling in deciduous forest soil differs between stands dominated by ecto- and arbuscular mycorrhizal trees. New Phytologist 209: 1184-1195.

Rodrigues A, Mueller UG, Ishak HD, Bacci Jr M, Pagnocca FC, 2011. Ecology of microfungal communities in gardens of fungusgrowing ants (Hymenoptera: Formicidae): a year-long survey of three species of attine ants in Central Texas. FEMS Microbiology Ecology 78: 244-255.

Rodrigues AM, Cruz Choappa R, Fernandes GF, De Hoog GS, De Camargo ZP, 2016. Sporothrix chilensis sp. nov. (Ascomycota: Ophiostomatales), a soil-borne agent of human sporotrichosis with mild-pathogenic potential to mammals. Fungal Biology 120: $246-264$.

Roets F, Wingfield BD, De Beer ZW, Wingfield MJ, Dreyer LL, 2010. Two new Ophiostoma species from Protea caffra in Zambia. Persoonia 24: 18-28.

Roets F, Wingfield MJ, Crous PW, Dreyer LL, 2013. Taxonomy and ecology of ophiostomatoid fungi associated with Protea infructescences. In: Seifert KA, De Beer ZW, Wingfield MJ (eds), The Ophiostomatoid Fungi. CBS, Utrecht, The Netherlands, pp. 177-187.

Ryberg M, 2015. Molecular operational taxonomic units as approximations of species in the light of evolutionary models and empirical data from Fungi. Molecular Ecology 24: 5770-5777.

Ryberg M, Nilsson RH, Kristiansson E, Topel M, Jacobsson S, Larsson E, 2008. Mining metadata from unidentified ITS sequences in GenBank: a case study in Inocybe (Basidiomycota). BMC Evolutionary Biology 8: 50.

Schoch CL, Robbertse B, Robert V, Vu D, Cardinali G, Irinyi L, Meyer W, Nilsson RH, Hughes K, Miller AN, Kirk PM, Abarenkov K, Aime MC, Ariyawansa HA, Bidartondo M, Boekhout T, Buyck B, Cai Q, Chen J, Crespo A, Crous PW, Damm U, De Beer ZW, Dentinger BTM, Divakar PK, Dueñas M, Feau N, Fliegerova K, García MA, Ge Z-W, Griffith GW, Groenewald JZ, Groenewald M, Grube M, Gryzenhout M, Gueidan C, Guo L, Hambleton S, Hamelin R, Hansen K, Hofstetter V, Hong S-B, Houbraken J, Hyde KD, Inderbitzin P, Johnston PR, Karunarathna SC, Kõljalg U, Kovács GM, Kraichak E, Krizsan K, Kurtzman CP, Larsson K-H, Leavitt S, Letcher PM, Liimatainen K, Liu J-K, Lodge DJ, Jennifer Luangsaard J, Lumbsch HT, Maharachchikumbura SSN, Manamgoda D, Martín MP, Minnis AM, Moncalvo J-M, Mulè G, Nakasone KK, Niskanen T, Olariaga I, Papp T, Petkovits T, Pino-Bodas R, Powell MJ, Raja HA, Redecker D, Sarmiento-Ramirez JM, Seifert KA, Shrestha B, Stenroos S, Stielow B, Suh S-O, Tanaka K, Tedersoo L, Telleria MT, Udayanga D, Untereiner WA, Diéguez Uribeondo J, Subbarao KV Vágvölgyi C, Visagie C, Voigt K, Walker DM, Weir BS, Weiß M, Wijayawardene NN, Wingfield MJ, Xu JP, Yang ZL, Zhang N, Zhuang W-Y, Federhen S, 2014. Finding needles in haystacks: linking scientific names, reference specimens and molecular data for Fungi. Database. http: //dx.doi.org/10.1093/database/bau061.

Schoch CL, Seifert KA, Huhndorf S, Robert V, Spouge JL, Levesque CA, Chen W, Bolchacova E, Voigt K, Crous PW, Miller AN, Wingfield MJ, Aime MC, An KD, Bai FY, Barreto RW, Begerow D, Bergeron MJ, Blackwell M, Boekhout T, Bogale M, Boonyuen N, Burgaz AR, Buyck B, Cai L, Cai Q, Cardinali G, Chaverri P, Coppins BJ, Crespo A, Cubas P, Cummings C, Damm U, de Beer ZW, de Hoog GS, Del-Prado R, Dentinger B, Dieguez-Uribeondo J, Divakar PK, Douglas B, Duenas M, Duong TA, Eberhardt U, Edwards JE, Elshahed MS, Fliegerova K, Furtado M, Garcia MA, Ge ZW, Griffith GW, Griffiths K, Groenewald JZ, Groenewald M, Grube M, Gryzenhout M, Guo LD, Hagen F, Hambleton S, Hamelin RC, Hansen K, Harrold P, Heller G, Herrera G, Hirayama K, Hirooka Y, Ho HM, Hoffmann K, Hofstetter V, Hognabba F, Hollingsworth PM, Hong SB, Hosaka K, Houbraken J, Hughes K, Huhtinen S, Hyde KD, James T, Johnson EM, Johnson JE, Johnston PR, Jones EB, Kelly LJ, Kirk PM, Knapp DG, Koljalg U, Kovacs GM, Kurtzman CP, Landvik S, Leavitt SD, Liggenstoffer AS, Liimatainen K, Lombard L, Luangsa-Ard JJ, Lumbsch HT, Maganti H, Maharachchikumbura SS, Martin MP, May TW, McTaggart AR, Methven AS, Meyer W, Moncalvo JM, Mongkolsamrit S, Nagy LG, Nilsson RH, Niskanen T, Nyilasi I, Okada G, Okane I, Olariaga I, Otte J, Papp T, Park D, Petkovits T, Pino-Bodas R, Quaedvlieg W, Raja HA, Redecker D, Rintoul T, Ruibal C, SarmientoRamirez JM, Schmitt I, Schussler A, Shearer C, Sotome K, Stefani FO, Stenroos S, Stielow B, Stockinger H, Suetrong S, Suh SO, Sung GH, Suzuki M, Tanaka K, Tedersoo L, Telleria MT, Tretter E, Untereiner WA, Urbina H, Vagvolgyi C, Vialle A, Vu TD, Walther G, Wang QM, Wang Y, Weir BS, Weiss M, White MM, Xu J, Yahr R, Yang ZL, Yurkov A, Zamora JC, Zhang N, Zhuang WY, Schindel D, Fungal Barcoding C, 2012. Nuclear ribosomal internal transcribed spacer (ITS) region as a universal DNA barcode marker for fungi. PNAS 109: 6241-6246.

Seifert KA, 2009. Progress towards DNA barcoding of fungi. Molecular Ecology Resources 9: 83-89.

Shrestha P, Szaro TM, Bruns TD, Taylor JW, 2011. Systematic search for cultivatable fungi that best deconstruct cell walls of Miscanthus and sugarcane in the field. Applied and Environmental Microbiology 77: 5490-5504. 
Stielow JB, Lévesque CA, Seifert KA, Meyer W, Irinyi L, Smits D, Renfurm R, Verkley GJM, Groenewald M, Chaduli D, Lomascolo A, Welti S, Lesage-Meessen L, Favel A, AlHatmi AMS, Damm U, Yilmaz N, Houbraken J, Lombard L, Quaedvlieg W, Binder M, Vaas LAI, Vu D, Yurkov A, Begerow D, Roehl O, Guerreiro M, Fonseca A, Samerpitak K, Van Diepeningen AD, Dolatabadi S, Moreno LF, Casaregola S, Mallet S, Jacques N, Roscini L, Egidi E, Bizet C, GarciaHermoso D, Martín MP, Deng S, Groenewald JZ, Boekhout T, De Beer ZW, Barnes I, Duong TA, Wingfield MJ, De Hoog GS, Crous PW, Lewis CT, Hambleton S, Moussa TAA, AlZahrani HS, Almaghrabi OA, Louis-Seize G, Assabgui R, McCormick W, Omer G, Dukik K, Cardinali G, Eberhardt U, De Vries M, Robert V, 2015. One fungus, which genes? Development and assessment of universal primers for potential secondary fungal DNA barcodes. Persoonia 35: 242-263.

Tamura K, Stecher G, Peterson D, Filipski A, Kumar S, 2013. MEGA6: molecular evolutionary genetics analysis version 6.0. Molecular Biology and Evolution 30: 2725-2729.

Taylor JW, 2011. One fungus = one name: DNA and fungal nomenclature twenty years after PCR. IMA Fungus 2: 113-120.

Taylor JW, Hibbett DS, 2013. Toward sequence-based classification of fungal species. IMA Fungus 4: 33-34.

Taylor JW, Jacobson DJ, Kroken S, Kasuga T, Geiser DM, Hibbett DS, Fisher MC, 2000. Phylogenetic species recognition and species concepts in fungi. Fungal Genetics and Biology 31: $21-32$.

Taylor JW, Turner E, Pringle A, Dettman J, Johannesson H, 2006a. Fungal species: thoughts on their recognition, maintenance and selection. In: Gadd GM, Watkinson SC, Dyer PS (eds), Fungi in the Environment. Cambridge University Press, Cambridge, UK, pp. 313-339.

Taylor JW, Turner E, Townsend JP, Dettman JR, Jacobson D, 2006b. Eukaryotic microbes, species recognition and the geographic limits of species: examples from the kingdom Fungi. Philosophical Transactions of the Royal Society B: Biological Sciences 361: 1947-1963.

Tripp EA, Lendemer JC, 2012. (4-5) Request for binding decisions on the descriptive statements associated with Mortierella sigyensis (fungi: Mortierellaceae) and Piromyces cryptodigmaticus (fungi: Neocallimastigaceae). Taxon 61: 886-888.

Vargas-Asensio G, Pinto-Tomas A, Rivera B, Hernandez M, Hernandez C, Soto-Montero S, Murillo C, Sherman DH, Tamayo-Castillo G, 2014. Uncovering the cultivable microbial diversity of Costa Rican beetles and its ability to break down plant cell wall components. PLoS One 9: e113303.

Vellinga EC, Kuyper TW, Ammirati J, Desjardin DE, Halling RE, Justo A, Læssøe T, Lebel T, Lodge DJ, Matheny PB, Methven AS, Moreau P-A, Mueller GM, Noordeloos ME, Nuytinck J, Ovrebo CL, Verbeken A, 2015. Six simple guidelines for introducing new genera of fungi. IMA Fungus 6: 65-68.

White TJ, Bruns T, Lee S, Taylor J, 1990. Amplification and direct sequencing of fungal ribosomal RNA genes for phylogenetics. In: Innis MA, Gelfand DH, Sninsky JJ, White TJ (eds), PCR Protocols: a guide to methods and application. Academic Press, San Diego, USA, pp. 315-322.

Yin M, Duong T, Wingfield M, Zhou X, De Beer ZW, 2015. Taxonomy and phylogeny of the Leptographium procerum complex, including Leptographium sinense sp. nov. and Leptographium longiconidiophorum sp. nov. Antonie van Leeuwenhoek 107: 547-563.

Yin M, Wingfield MJ, Zhou X, De Beer ZW, 2016. Multigene phylogenies and morphological characterization of five new Ophiostoma spp. associated with spruce-infesting bark beetles in China. Fungal Biology 120: 454-470.

Zhang Z, Schwartz S, Wagner L, Miller W, 2000. A greedy algorithm for aligning DNA sequences. Journal of Computational Biology 7: 203-214. 